\title{
A chilled margin of komatiite and Mg-rich basaltic andesite in the western Bushveld Complex, South Africa
}

\author{
W. D. Maier ${ }^{1}$ S.-J. Barnes ${ }^{2}$ B. T. Karykowski ${ }^{1}$
}

Received: 11 January 2016 / Accepted: 28 March 2016 / Published online: 27 May 2016

(C) The Author(s) 2016. This article is published with open access at Springerlink.com

\begin{abstract}
A chill sequence at the base of the Lower Zone of the western Bushveld Complex at Union Section, South Africa, contains aphanitic Mg-rich basaltic andesite and spinifex-textured komatiite. The basaltic andesite has an average composition of $15.2 \% \mathrm{MgO}, 52.8 \% \mathrm{SiO}_{2}$, $1205 \mathrm{ppm} \mathrm{Cr}$, and $361 \mathrm{ppm} \mathrm{Ni}$, whereas the komatiite has $18.7 \% \mathrm{MgO}, 1515 \mathrm{ppm} \mathrm{Cr}$, and $410 \mathrm{ppm} \mathrm{Ni}$. Both rock types have very low concentrations of immobile incompatible elements (0.14-0.72 ppm Nb, 7-31 ppm Zr, 0.34$0.69 \mathrm{ppm}$ Th, $0.23-0.27 \mathrm{wt} \% \mathrm{TiO}_{2}$ ), but high PGE contents (19-23 ppb Pt, 15-16 ppb Pd) and Pt/Pd ratios (Pt/Pd 1.4). Strontium and $\mathrm{S}$ isotopes show enriched signatures relative to most other Lower Zone rocks. The rocks could represent a $\sim 20 \%$ partial melt of subcontinental lithospheric mantle. This would match the PGE content of the rocks. However, this model is inconsistent with the high $\mathrm{SiO}_{2}, \mathrm{Fe}$, and $\mathrm{Na}_{2} \mathrm{O}$ contents and, in particular, the low $\mathrm{K}_{2} \mathrm{O}, \mathrm{Zr}, \mathrm{Hf}, \mathrm{Nb}, \mathrm{Ta}$, Th, LREE, $\mathrm{Rb}$, and $\mathrm{Ba}$ contents of the rocks. Alternatively, the chills could represent a komatiitic magma derived from the asthenosphere that underwent assimilation of the quartzitic floor accompanied by crystallization of olivine and chromite. This model is consistent with the lithophile elements
\end{abstract}

Communicated by Timothy L. Grove.

Electronic supplementary material The online version of this article (doi:10.1007/s00410-016-1257-5) contains supplementary material, which is available to authorized users.

W. D. Maier

maierw@cardiff.ac.uk

1 School of Earth and Ocean Sciences, Cardiff University, Cardiff, UK

2 Sciences de la Terre, Université du Québec à Chicoutimi, Chicoutimi, QC, Canada and the elevated $\mathrm{Sr}$ and $\mathrm{S}$ isotopic signatures of the rocks. However, in order to account for the high Pt and Pd contents of the magma, the mantle must have been twice as rich in PGE as the current estimate for PUM, possibly due to a component of incompletely equilibrated late veneer.

Keywords Komatiite $\cdot$ Basaltic andesite $\cdot$ Bushveld Complex $\cdot$ Chilled margin $\cdot$ Subcontinental lithospheric mantle

\section{Introduction}

The Bushveld Complex is the product of what was one of the world's largest magmatic events, comprising the largest layered mafic-ultramafic intrusion globally (the $400 \times 300 \mathrm{~km}$ Bushveld Complex) plus the $\sim 150 \times 100 \mathrm{~km}$ Molopo Farms Complex in Botswana (von Gruenewaldt et al. 1989; Reichhardt 1994), a number of mafic-ultramafic complexes located up to $>100 \mathrm{~km}$ to the $\mathrm{S}$ and SW of the Bushveld Complex (de Waal et al. 2006), the Phalaborwa carbonatite located $>100 \mathrm{~km}$ to the east of the Bushveld (Reischmann 1995), and several other small intrusions (Rajesh et al. 2013, and references therein). Associated with these mafic rocks is the largest A-type granite on Earth (the Lebowa Granite Suite, Walraven and Hattingh 1993) and a vast rhyolitic lava flow field (the Rooiberg felsites) whose remnants are preserved over $800 \mathrm{~km}$ in EW direction and $300 \mathrm{~km}$ in NS direction (Twist and French 1983). The Bushveld Complex and its country rocks host the world's largest PGE, $\mathrm{Cr}, \mathrm{V}$, as well as vast $\mathrm{Ni}-\mathrm{Cu}$, gold, andalusite, magnesite, and dimension stone resources, and numerous other mineral deposits (Anhaeusser and Maske 1986; Wilson and Anhaeusser 1998). In order to better understand the petrogenesis of this unusually voluminous and economically 
Fig. 1 Geological map of the Bushveld Complex, showing localities mentioned in the text (modified from Maier et al. 2013). TML Thabazimbi Murchison Lineament, $B G$ Brits Graben, $C R F$ Crocodile River fault, $W F$ Wonderkop fault, $S F$ Steelpoort fault

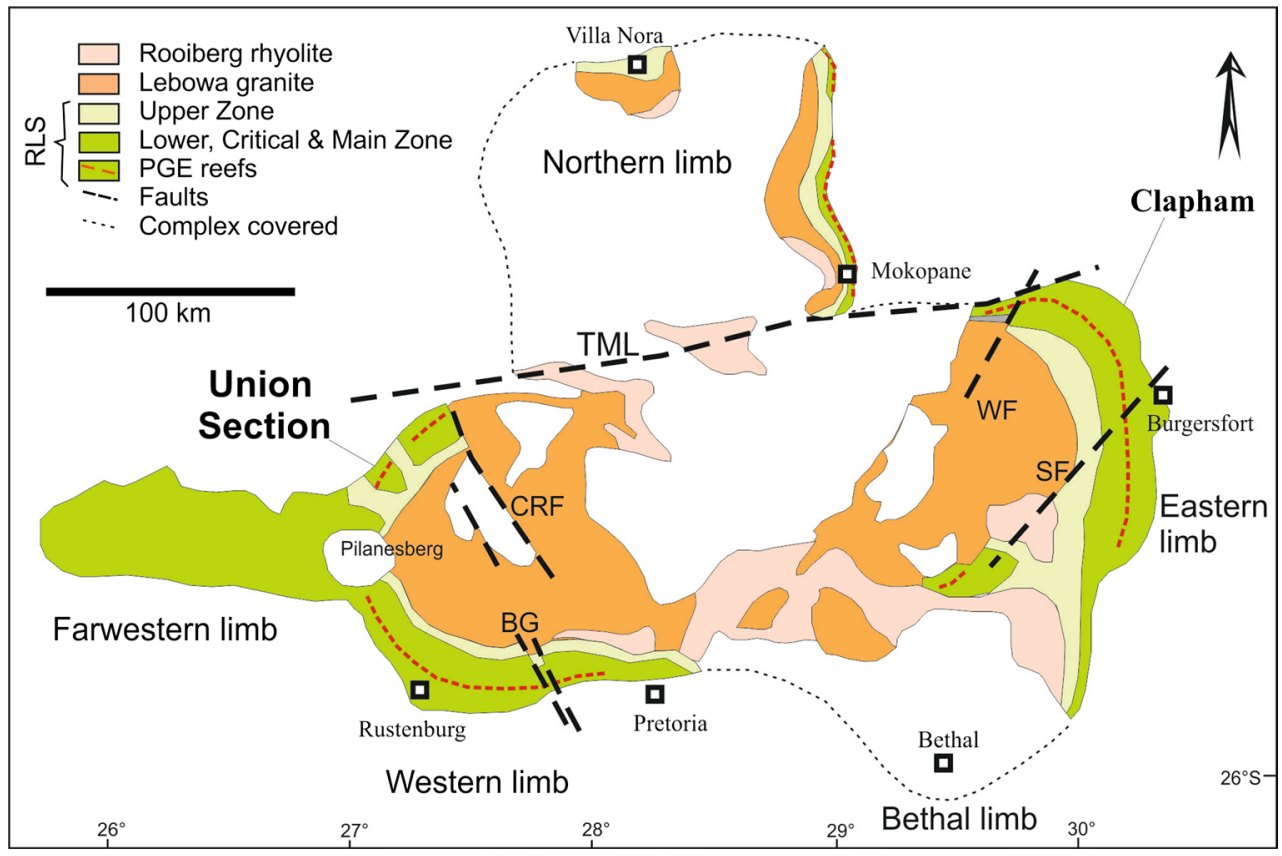

important event, it is critically important to know the composition of the parent magmas to the mafic-ultramafic cumulate rocks. Fortunately, the Bushveld Complex is one of few mafic-ultramafic intrusions where the parent magma composition could be studied in considerable detail, based on a suite of fine-grained, relatively unaltered sills exposed in the floor of the Complex (Davies et al. 1980; Cawthorn et al. 1981; Sharpe 1981; Barnes et al. 2010). Chilled margins also occur, albeit relatively rarely, and their study has only begun relatively recently (Wilson 2012). Here, we present compositional data from a relatively unevolved chill sequence which overlies quartzite at Union Section in the western Bushveld Complex (Fig. 1). We evaluate how these magmas are related to other examples of Bushveld marginal rocks and what their compositions tell us about the mantle source of the Bushveld magmatism.

\section{The parent magmas to the Bushveld Complex: a half century of controversy}

The nature of the mantle sources to the Bushveld Complex has been debated since the advent of $\mathrm{Sr}$ isotope studies, nearly a half century ago (Davies et al. 1970; Hamilton 1977). The first study on potential Bushveld parent magmas was published by Davies et al. (1980) in which the authors described a suite of fine-grained noritic sills of $\mathrm{Mg}$ rich basaltic andesite composition (9-13\% MgO). In what proved to be a seminal paper, Sharpe (1981) introduced a classification for the fine-grained suite of sills underlying the Bushveld. The Bushveld 1 (B1) magma underlies the Lower Zone, B2 underlies the Upper Critical Zone, and B3 underlies the Main Zone. Strontium and Nd isotopes for these suites were determined by Harmer and Sharpe (1985) and Curl (2001), and platinum-group elements (PGE) by Davies and Tredoux (1985) and Barnes et al. (2010). The present paper deals with the B1 suite, previously described as having $\mathrm{MgO}$ contents of up to $16.5 \mathrm{wt} \%$ (average $\sim 13 \mathrm{wt} \% \mathrm{MgO}$ ) and high levels of compatible trace elements (up to $\sim 1500 \mathrm{ppm} \mathrm{Cr}, \sim 500 \mathrm{ppm} \mathrm{Ni}$ ), but at the same time also high $\mathrm{SiO}_{2}$ contents (50-57 wt\%) and incompatible trace elements (e.g., up to $23 \mathrm{ppm} \mathrm{La).} \mathrm{Incompatible} \mathrm{trace}$ element patterns of the rocks show pronounced negative $\mathrm{Nb}-\mathrm{Ta}$ and $\mathrm{Ti}$ anomalies, and $\mathrm{Pt} / \mathrm{Pd}$ and $\mathrm{PGE} / \mathrm{Ti}$ ratios are unusually high (Barnes et al. 2010). They have been referred to as boninites, siliceous high-Mg basalt (SHMB) or magnesian andesite. The question at the center of the debate has been whether these unusual compositional traits are due to crustal contamination of a komatiitic parent magma (Barnes 1989; Maier et al. 2000), melting of metasomatized SCLM (Harmer and Sharpe 1985; Maier and Barnes 2004; Richardson and Shirey 2008), or a combination thereof (Barnes et al. 2010). No conclusive geochemical traits have yet been identified that rule out one of these two models. The most recent contribution on the topic has been by Wilson (2012) who identified an $8 \mathrm{~m}$ sequence of high-Fo (up to $91.2 \%$ ) olivine overlying a magnesian andesitic chilled margin at Clapham in the eastern Bushveld Complex. The author went on to propose that these olivines crystallized from a komatiitic magma with approximately 18-19 wt\% $\mathrm{MgO}$. In the following, we will evaluate the different models, based on the composition of a chill sequence exposed in drill core at Union Section, northwestern Bushveld Complex. 
Table 1 Precision and accuracy of PGE analyses

\begin{tabular}{|c|c|c|c|c|c|c|c|c|c|c|c|c|c|c|c|}
\hline & & \multicolumn{2}{|c|}{$99 \mathrm{Ru}$} & \multicolumn{2}{|c|}{$103 \mathrm{Rh}$} & \multicolumn{2}{|c|}{$105 \mathrm{Pd}$} & \multicolumn{2}{|c|}{189 Os } & \multicolumn{2}{|c|}{$193 \mathrm{Ir}$} & \multicolumn{2}{|l|}{$195 \mathrm{Pt}$} & \multicolumn{2}{|c|}{$197 \mathrm{Au}$} \\
\hline & & $\mathrm{ng} / \mathrm{g}$ & \pm & $\mathrm{ng} / \mathrm{g}$ & \pm & $\mathrm{ng} / \mathrm{g}$ & \pm & $\mathrm{ng} / \mathrm{g}$ & \pm & $\mathrm{ng} / \mathrm{g}$ & \pm & $\mathrm{ng} / \mathrm{g}$ & \pm & $\mathrm{ng} / \mathrm{g}$ & \pm \\
\hline OKUM & This run UQAC $^{\mathrm{a}}$ & 4.3 & 0.18 & 1.4 & 0.07 & 11.99 & 0.47 & 0.74 & 0.1 & 0.9 & 0.06 & 10.44 & 0.42 & 0.99 & 0.43 \\
\hline OKUM & Geo Labs (2001) & 4.25 & 0.3 & 1.4 & 0.13 & 11.7 & 0.5 & na & & 0.99 & 0.07 & 11 & 0.6 & 1.41 & 0.57 \\
\hline OKUM & Savard et al. (2010) & 4.15 & 0.08 & na & & 12.2 & 0.73 & 0.79 & & 0.94 & 0.04 & 11.44 & 0.22 & na & \\
\hline
\end{tabular}

${ }^{a} \mathrm{Ni}-\mathrm{FA}-\mathrm{Te}-\mathrm{Co}-$ pre-ICP-MS + HPA-ID

\section{Methods}

After the production of polished thin sections, drill core samples measuring between 10 and $20 \mathrm{~cm}$ in length were crushed in a jaw crusher and milled in agate. The concentrations of the lithophile elements were determined by ICP-OES and ICP-MS at Cardiff University following the method described in McDonald and Viljoen (2006). The PGE and Au were determined by ICP-MS after Ni-sulfide fire assay at the University of Quebec at Chicoutimi, Canada (see Table 1 for accuracy and precision). The major elements of one of the samples were additionally analyzed by XRF (Table 2) allowing to evaluate potential laboratory bias. For another sample, trace elements were additionally analyzed by ICP-MS at the University of Cape Town (Table 2). One sample was analyzed for $\mathrm{S}$ isotopes using laser ICP-MS at the Geological Survey of Finland (see Molnár et al. 2016 for analytical details). In another sample, we determined $\mathrm{Sr}$ isotopes in plagioclase, also by laser ICP-MS in Finland (see Yang et al. 2013 for analytical details). Element maps and mineral compositions of two chill samples were produced/determined using a Zeiss Sigma HD Analytical SEM at Cardiff University. All whole-rock compositional data are provided in Table 3.

\section{Locality of the Nooitgedacht boreholes}

The chill sequence studied here was intersected at the bottom of the Nooitgedacht 2 (NG2) borehole, one of a series of 3 boreholes drilled by the Geological Survey of South Africa in 1986-1987 at Union Section in the western Bushveld Complex as part of the National Geoscience Program (Fig. 1). The drill cores were first analyzed in detail by Teigler (1990) and Teigler and Eales (1996). Borehole NG1 intersected the upper portion of the Lower Zone and the bulk of the Lower Critical Zone, borehole NG3 the lower portion of the Upper Critical Zone, whereas borehole NG2 intersected the Lower Zone and the basal contact of the intrusion (Fig. 2). The latter is characterized by several quartzite xenoliths and a $90-\mathrm{cm}$ fine-grained to aphanitic chill sequence overlying quartzite interpreted to represent the floor rocks of the intrusion. The intersected sequence represents the first chilled margin identified at the base of the Lower Zone sensu strictu of the Bushveld Complex.

\section{Stratigraphy of the chill sequence}

Photographs of the basal $8 \mathrm{~m}$ of the NG2 drill core are shown in Figs. 3 and 4 and Electronic Appendix 1. The floor rocks to the Bushveld Complex consist of a $30 \mathrm{~cm}$ interval of banded magnetite- and sulfide-bearing quartzite containing irregular masses of massive quartzite (Fig. 3). Because the borehole was stopped after intersecting a mere $30 \mathrm{~cm}$ of quartzite, it cannot be ruled out that the latter represents a xenolith. However, as the thickness of the basal compositional reversal ( $300 \mathrm{~m}$, Teigler 1990a) resembles that in other layered intrusions and because the intersected chill/quench sequence has a similar width $(90 \mathrm{~cm})$ and broadly similar stratigraphy (a basal aphanitic chill, overlain by spinifex-textured and medium-grained rocks) as that described by Wilson (2012) from the eastern Bushveld Complex, we argue that the quartzite represents the floor of the intrusion. Alternatively, it could represent a very large xenolith, but this would not alter our interpretations.

The basal contact of the Bushveld intrusion at $774.43 \mathrm{~m}$ is sharp and overlain by $10 \mathrm{~cm}$ of fine-grained rock having the composition of Mg-rich basaltic andesite interpreted to be the chilled margin of the Bushveld Lower Zone. The chilled rock contains a $\sim 1 \mathrm{~cm}$ wide, fine- to mediumgrained, sulfide-rich ultramafic microsill near its base that will be further described in the next section. Above the chilled rock is a 11-cm medium-grained quartz- and phlogopite-rich melagabbronorite (at $774.22-774.33 \mathrm{~m}$ ), overlain by a $72 \mathrm{~cm}$ weakly banded zone of fine-grained, spinifex-textured mafic rock (from 774.22 to $773.5 \mathrm{~m}$ ), containing a thin medium-grained gabbroic lens. The fine-grained mafic interval is overlain by medium-grained gabbronorite showing elongated plagioclase and pyroxene crystals $(773.5-773.35 \mathrm{~m})$, and then medium-grained olivine orthopyroxenite (to $766.91 \mathrm{~m}$ ), containing a felsic melt vein near the top.

The interval from 766.91 to 766.0 contains three irregular xenoliths of quartzite (Electronic Appendix 1). One of the quartzite xenoliths contains 2 rounded "inclusions" or injections of pegmatoidal gabbronorite and pyroxenite. In 
Table 2 Duplicate analyses of selected samples

\begin{tabular}{|c|c|c|c|c|c|c|c|c|c|}
\hline \multirow[t]{3}{*}{ Sample } & $\begin{array}{l}\text { ICP-MS } \\
\text { Cardiff }\end{array}$ & $\begin{array}{l}\text { XRF } \\
\text { Teigler }\end{array}$ & $\begin{array}{l}\text { ICP-MS } \\
\text { Cardiff }\end{array}$ & $\begin{array}{l}\text { XRF } \\
\text { Teigler }\end{array}$ & $\begin{array}{l}\text { ICP-MS } \\
\text { UCT }\end{array}$ & $\begin{array}{l}\text { ICP-MS } \\
\text { UCT }\end{array}$ & $\begin{array}{l}\text { ICP-MS } \\
\text { UCT }\end{array}$ & $\begin{array}{l}\text { ICP-MS } \\
\text { UCT }\end{array}$ & $\begin{array}{l}\text { ICP-MS } \\
\text { UCT }\end{array}$ \\
\hline & & 1990 & & 1990 & & & & & \\
\hline & 773.43 & & 773.95 & & & $\%$ RSD & Blank & BHV02 & $\%$ RSD \\
\hline $\mathrm{SiO}_{2}(\mathrm{wt} \%)$ & 52.87 & 53.4 & 50.63 & 51.7 & na & & & & \\
\hline $\mathrm{TiO}_{2}$ & 0.49 & 0.5 & 0.27 & 0.3 & na & & & & \\
\hline $\mathrm{Al}_{2} \mathrm{O}_{3}$ & 9.34 & 10.6 & 10.11 & 10.6 & na & & & & \\
\hline $\mathrm{Fe}_{2} \mathrm{O}_{3}$ & 11.84 & 10 & 11.98 & 11.4 & na & & & & \\
\hline $\mathrm{MnO}$ & 0.17 & 0.2 & 0.23 & 0.2 & na & & & & \\
\hline $\mathrm{MgO}$ & 15.07 & 15.3 & 18.64 & 17.5 & na & & & & \\
\hline $\mathrm{CaO}$ & 7.44 & 7.2 & 6.92 & 6.6 & na & & & & \\
\hline $\mathrm{Na}_{2} \mathrm{O}$ & 1.35 & 1.9 & 0.87 & 1.2 & na & & & & \\
\hline $\mathrm{K}_{2} \mathrm{O}$ & 0.64 & 0.7 & 0.19 & 0.2 & na & & & & \\
\hline $\mathrm{P}_{2} \mathrm{O}_{5}$ & 0.08 & 0.1 & 0.05 & 0.1 & na & & & & \\
\hline LOI & 0.95 & & 0.14 & & na & & & & \\
\hline Total & 100.23 & 100 & 100.03 & 100 & na & & & & \\
\hline $\mathrm{V}(\mathrm{ppm})$ & 166 & 159 & 144 & 171 & 165 & 0.408 & 0.01 & 309.4 & 0.701 \\
\hline $\mathrm{Cr}$ & 1105 & 1334 & 1311 & 1635 & 1288 & 0.273 & 0.019 & 273.3 & 0.469 \\
\hline $\mathrm{Ni}$ & 566 & 442 & 392 & 450 & na & & & & \\
\hline $\mathrm{Cu}$ & 44 & 39 & 43 & 17 & 9.167 & 1.144 & 0.078 & 127.5 & 0.263 \\
\hline $\mathrm{Rb}$ & 27.00 & 26 & 5 & 8 & 6.258 & 0.301 & 0.007 & 8.637 & 0.272 \\
\hline $\mathrm{Sr}$ & 201 & 213 & 189 & 216 & 181 & 0.711 & 0.027 & 378.7 & 0.581 \\
\hline Y & 10.70 & 15 & 6.8 & 10 & 6.974 & 0.961 & 0.004 & 24.38 & 0.216 \\
\hline $\mathrm{Zr}$ & 31 & 25 & 10.4 & 7 & 7.335 & 0.610 & 0.014 & 168.5 & 0.191 \\
\hline $\mathrm{Nb}$ & na & na & 0.72 & na & 0.488 & 2.274 & 0.018 & 17.82 & 0.338 \\
\hline Cs & na & na & 0.34 & na & 0.358 & 0.352 & 0.005 & 0.087 & 1.139 \\
\hline $\mathrm{La}$ & na & na & 6.75 & na & 8.627 & 0.172 & 0.004 & 14.58 & 0.352 \\
\hline $\mathrm{Ce}$ & na & na & 11.81 & na & 16.82 & 0.471 & 0.006 & 36.80 & 0.655 \\
\hline $\operatorname{Pr}$ & na & na & 1.46 & na & 1.871 & 0.340 & 0.003 & 5.214 & 0.634 \\
\hline $\mathrm{Nd}$ & na & na & 6.04 & na & 7.018 & 0.825 & 0.004 & 24.11 & 0.341 \\
\hline $\mathrm{Sm}$ & na & na & 1.3 & na & 1.285 & 1.006 & 0.003 & 5.910 & 0.302 \\
\hline $\mathrm{Eu}$ & na & na & 0.46 & na & 0.467 & 1.249 & 0.004 & 1.998 & 0.511 \\
\hline $\mathrm{Gd}$ & na & na & 1.12 & na & 1.181 & 1.506 & 0.003 & 5.938 & 0.977 \\
\hline $\mathrm{Tb}$ & na & na & 0.17 & na & 0.187 & 1.178 & 0.003 & 0.866 & 0.762 \\
\hline Dy & na & na & 1.17 & na & 1.220 & 0.708 & 0.004 & 5.072 & 0.383 \\
\hline Ho & na & na & 0.24 & na & 0.258 & 0.608 & 0.003 & 0.924 & 0.107 \\
\hline $\mathrm{Er}$ & na & na & 0.69 & na & 0.782 & 1.023 & 0.004 & 2.406 & 0.517 \\
\hline $\mathrm{Tm}$ & na & na & 0.11 & na & 0.120 & 0.445 & 0.003 & 0.316 & 2.081 \\
\hline $\mathrm{Yb}$ & na & na & 0.78 & na & 0.834 & 1.200 & 0.003 & 1.915 & 1.270 \\
\hline $\mathrm{Lu}$ & na & na & 0.12 & na & 0.140 & 0.813 & 0.003 & 0.275 & 0.652 \\
\hline $\mathrm{Hf}$ & na & na & 0.29 & na & 0.228 & 1.193 & 0.004 & 4.296 & 0.342 \\
\hline $\mathrm{Ta}$ & na & na & 0.08 & na & 0.049 & 1.944 & 0.006 & 1.090 & 0.985 \\
\hline $\mathrm{Pb}$ & na & na & 2.15 & na & 0.856 & 2.015 & 0.016 & 1.528 & 0.374 \\
\hline Th & na & na & 0.34 & na & 0.327 & 1.189 & 0.004 & 1.231 & 0.184 \\
\hline U & na & na & 0.16 & na & 0.120 & 2.006 & 0.007 & 0.453 & 0.501 \\
\hline
\end{tabular}

contrast to the basal contact of the exposed sequence, the pyroxenite in the upper quartzite xenolith zone lacks chilled margins against the quartzite. The xenolith-rich interval is overlain by a further $3 \mathrm{~m}$ of harzburgite and then close to
$200 \mathrm{~m}$ of fine-grained pyroxenite containing numerous layers and lenses of medium-grained harzburgite ranging in thickness from a few centimeters to several $10 \mathrm{~s}$ of meters. The contacts between the pyroxenites and harzburgites are 
Table 3 Whole-rock composition of samples from the basal chill sequence, NG2 drill core

\begin{tabular}{|c|c|c|c|c|c|c|c|c|c|c|c|c|c|c|}
\hline & 1 & 3 & 5 & BT773.95 & BT773.7 & 7 & 9 & 10 & 11 & 12 & 13 & 15 & 16 & 17 \\
\hline Top & 774.58 & 774.37 & 774.16 & 773.9 & 773.6 & 773.45 & 773.07 & 772.81 & 772.49 & 772.22 & 771.83 & 769.75 & 768.69 & 767.89 \\
\hline Base & 774.62 & 774.43 & 774.19 & 773.95 & 773.7 & 773.5 & 773.13 & 772.93 & 772.59 & 772.31 & 771.91 & 769.81 & 768.76 & 767.95 \\
\hline Rock type & Quarzite & Chill & Chill & Chill & Chill & Nor & OlPx & OlPx & OlPx & OlPx & OlPx & OlPx & OlPx & OlPx \\
\hline $\mathrm{SiO}_{2}(\mathrm{wt} \%)$ & 86.43 & 52.24 & 53.07 & 50.63 & 52.25 & 52.87 & 51.14 & 50.52 & 50.87 & 49.35 & 48.79 & 47.98 & 48.20 & 48.65 \\
\hline $\mathrm{TiO}_{2}$ & 0.11 & 0.23 & 0.26 & 0.27 & 0.25 & 0.49 & 0.37 & 0.35 & 0.34 & 0.30 & 0.31 & 0.30 & 0.30 & 0.27 \\
\hline $\mathrm{Al}_{2} \mathrm{O}_{3}$ & 4.71 & 10.34 & 8.86 & 10.11 & 10.04 & 9.34 & 7.55 & 7.09 & 6.48 & 5.99 & 5.83 & 5.72 & 5.70 & 5.15 \\
\hline $\mathrm{Fe}_{2} \mathrm{O}_{3}$ & 1.92 & 13.36 & 14.47 & 11.98 & 11.04 & 11.84 & 11.81 & 11.72 & 11.97 & 11.48 & 12.08 & 11.87 & 11.79 & 11.81 \\
\hline $\mathrm{MnO}$ & 0.03 & 0.18 & 0.21 & 0.23 & 0.20 & 0.17 & 0.15 & 0.15 & 0.15 & 0.15 & 0.15 & 0.15 & 0.16 & 0.15 \\
\hline $\mathrm{MgO}$ & 1.86 & 14.58 & 15.75 & 18.64 & 18.70 & 15.07 & 21.04 & 21.35 & 21.85 & 23.37 & 23.09 & 23.48 & 23.80 & 23.88 \\
\hline $\mathrm{CaO}$ & 2.38 & 7.35 & 6.45 & 6.92 & 6.38 & 7.44 & 5.00 & 4.79 & 4.57 & 4.29 & 4.41 & 4.03 & 3.86 & 3.72 \\
\hline $\mathrm{Na}_{2} \mathrm{O}$ & 1.11 & 0.89 & 0.95 & 0.87 & 1.34 & 1.35 & 0.89 & 0.92 & 0.89 & 0.81 & 0.72 & 0.66 & 0.64 & 0.49 \\
\hline $\mathrm{K}_{2} \mathrm{O}$ & 0.38 & 0.10 & 0.12 & 0.19 & 0.47 & 0.64 & 0.47 & 0.54 & 0.47 & 0.40 & 0.40 & 0.40 & 0.39 & 0.50 \\
\hline $\mathrm{P}_{2} \mathrm{O}_{5}$ & 0.15 & 0.06 & 0.04 & 0.05 & 0.03 & 0.08 & 0.06 & 0.06 & 0.05 & 0.06 & 0.07 & 0.04 & 0.04 & 0.05 \\
\hline LOI & 1.17 & 0.88 & 0.06 & 0.14 & 0.49 & 0.95 & 1.28 & 1.32 & 1.79 & 2.65 & 3.18 & 4.42 & 4.08 & 4.19 \\
\hline Total & 100.23 & 100.21 & 100.25 & 100.03 & 101.19 & 100.23 & 99.77 & 98.81 & 99.41 & 98.85 & 99.03 & 99.05 & 98.96 & 98.86 \\
\hline $\mathrm{Sc}(\mathrm{ppm})$ & 3.1 & 37 & 40 & 33 & 29 & 28 & 19 & 20 & 20 & 18 & 18 & 17 & 15 & 16 \\
\hline V & 32 & 187 & 214 & 144 & 105 & 166 & 158 & 162 & 147 & 153 & 143 & 146 & 147 & 149 \\
\hline $\mathrm{Cr}$ & 562 & 1259 & 1198 & 1312 & 1595 & 1105 & 1728 & 2206 & 2666 & 2450 & 3262 & 3680 & 3456 & 4225 \\
\hline Co & 4.2 & 66 & 73 & 57 & 67 & 71 & 98 & 100 & 104 & 96 & 106 & 105 & 102 & 113 \\
\hline $\mathrm{Zn}$ & 25 & 134 & 101 & 111 & 74 & 72 & 82 & 63 & 68 & 76 & 71 & 67 & 68 & 67 \\
\hline $\mathrm{Ga}$ & 6.40 & 13.81 & 8.98 & 8.91 & 8.36 & 9.97 & 8.05 & 7.89 & 7.69 & 6.67 & 7.19 & 6.74 & 6.08 & 6.46 \\
\hline $\mathrm{Rb}$ & 12.11 & 3.67 & 4.61 & 5.01 & 10.29 & 27.20 & 21.45 & 23.37 & 25.04 & 15.71 & 15.30 & 13.66 & 13.43 & 23.80 \\
\hline $\mathrm{Sr}$ & 69 & 210 & 160 & 189 & 198 & 201 & 129 & 118 & 119 & 97 & 104 & 92 & 85 & 84 \\
\hline $\mathrm{Y}$ & 5.69 & 16.42 & 7.58 & 6.77 & 7.14 & 10.70 & 7.53 & 8.20 & 7.59 & 7.08 & 7.43 & 6.57 & 6.21 & 6.12 \\
\hline $\mathrm{Zr}$ & 5.5 & 34 & 6.0 & 10 & 20 & 31 & 35 & 43 & 40 & 34 & 34 & 35 & 35 & 29 \\
\hline $\mathrm{Nb}$ & 0.18 & 0.55 & 0.14 & 0.72 & 0.98 & 2.36 & 1.76 & 2.17 & 1.88 & 1.45 & 1.65 & 1.52 & 1.61 & 1.43 \\
\hline Mo & 0.62 & 0.61 & 0.49 & 0.18 & 0.06 & 0.59 & 0.56 & 0.59 & 0.55 & 0.55 & 0.56 & 0.48 & 0.48 & 0.47 \\
\hline Cs & 0.39 & 0.44 & 0.39 & 0.34 & 0.61 & 1.11 & 1.41 & 1.22 & 1.45 & 0.75 & 0.66 & 0.74 & 0.65 & 1.34 \\
\hline $\mathrm{Ba}$ & 117 & 83 & 59 & 96 & 138 & 210 & 137 & 149 & 130 & 123 & 132 & 123 & 113 & 115 \\
\hline $\mathrm{La}$ & 19.2 & 13.2 & 5.6 & 6.7 & 5.1 & 8.2 & 6.9 & 8.0 & 7.0 & 6.8 & 7.5 & 6.0 & 5.9 & 6.0 \\
\hline $\mathrm{Ce}$ & 33.6 & 23.3 & 10.3 & 11.8 & 10.1 & 17.3 & 13.6 & 16.0 & 14.1 & 13.4 & 14.9 & 12.1 & 11.7 & 11.9 \\
\hline $\operatorname{Pr}$ & 3.68 & 2.52 & 1.26 & 1.46 & 1.39 & 2.25 & 1.72 & 1.98 & 1.69 & 1.66 & 1.80 & 1.46 & 1.43 & 1.43 \\
\hline $\mathrm{Nd}$ & 12.35 & 8.93 & 5.16 & 6.04 & 5.84 & 9.00 & 6.68 & 7.50 & 6.47 & 6.31 & 6.46 & 5.52 & 5.22 & 5.17 \\
\hline $\mathrm{Sm}$ & 1.89 & 1.68 & 1.08 & 1.30 & 1.25 & 1.97 & 1.30 & 1.43 & 1.43 & 1.29 & 1.35 & 1.20 & 1.07 & 1.10 \\
\hline $\mathrm{Eu}$ & 0.67 & 0.51 & 0.44 & 0.46 & 0.44 & 0.56 & 0.46 & 0.46 & 0.39 & 0.38 & 0.40 & 0.38 & 0.35 & 0.33 \\
\hline $\mathrm{Gd}$ & 1.59 & 2.06 & 0.97 & 1.12 & 1.21 & 1.93 & 1.25 & 1.46 & 1.22 & 1.22 & 1.38 & 0.95 & 0.93 & 0.95 \\
\hline $\mathrm{Tb}$ & 0.21 & 0.37 & 0.20 & 0.17 & 0.19 & 0.29 & 0.18 & 0.21 & 0.20 & 0.18 & 0.20 & 0.18 & 0.16 & 0.16 \\
\hline Dy & 0.92 & 2.54 & 1.18 & 1.17 & 1.26 & 1.84 & 1.20 & 1.38 & 1.23 & 1.16 & 1.22 & 1.06 & 1.01 & 0.97 \\
\hline Ho & 0.17 & 0.50 & 0.24 & 0.24 & 0.24 & 0.34 & 0.24 & 0.25 & 0.22 & 0.22 & 0.23 & 0.19 & 0.18 & 0.18 \\
\hline $\mathrm{Er}$ & 0.47 & 1.44 & 0.73 & 0.69 & 0.73 & 1.02 & 0.70 & 0.76 & 0.66 & 0.65 & 0.67 & 0.62 & 0.54 & 0.53 \\
\hline $\mathrm{Tm}$ & 0.06 & 0.23 & 0.13 & 0.11 & 0.11 & 0.17 & 0.11 & 0.12 & 0.10 & 0.10 & 0.10 & 0.09 & 0.09 & 0.08 \\
\hline $\mathrm{Yb}$ & 0.40 & 1.62 & 0.86 & 0.78 & 0.84 & 0.99 & 0.75 & 0.74 & 0.68 & 0.65 & 0.77 & 0.59 & 0.59 & 0.55 \\
\hline $\mathrm{Lu}$ & 0.05 & 0.24 & 0.15 & 0.12 & 0.12 & 0.16 & 0.12 & 0.12 & 0.11 & 0.10 & 0.11 & 0.09 & 0.08 & 0.07 \\
\hline $\mathrm{Hf}$ & 0.10 & 0.82 & 0.13 & 0.29 & 0.46 & 0.87 & 0.88 & 1.01 & 1.01 & 0.83 & 0.80 & 0.83 & 0.85 & 0.71 \\
\hline $\mathrm{Ta}$ & 0.02 & 0.04 & 0.01 & 0.08 & 0.07 & 0.14 & 0.12 & 0.14 & 0.13 & 0.11 & 0.12 & 0.10 & 0.12 & 0.12 \\
\hline $\mathrm{Pb}$ & 9.66 & 11.79 & 5.63 & 2.15 & 6.25 & 5.60 & 5.83 & 3.82 & 3.89 & 4.14 & 3.74 & 4.71 & 4.31 & 3.51 \\
\hline Th & 0.37 & 0.69 & 0.35 & 0.34 & 0.75 & 1.28 & 1.30 & 1.48 & 1.75 & 1.27 & 1.45 & 1.21 & 1.13 & 1.62 \\
\hline $\mathrm{U}$ & 0.03 & 0.07 & 0.01 & 0.16 & 0.20 & 0.37 & 0.30 & 0.32 & 0.39 & 0.27 & 0.42 & 0.31 & 0.26 & 0.39 \\
\hline
\end{tabular}


Table 3 continued

\begin{tabular}{lllllllllllllll}
\hline & 1 & 3 & 5 & BT773.95 & BT773.7 & 7 & 9 & 10 & 11 & 12 & 13 & 15 & 16 & 17 \\
\hline $\mathrm{Ni}$ & 14 & 359 & 339 & 392 & 602 & 566 & 1189 & 1252 & 1234 & 1288 & 1259 & 1441 & 1363 & 1512 \\
$\mathrm{~S}$ & 822 & 3689 & 4072 & 886 & 664 & 305 & 1002 & 687 & 461 & 573 & 635 & 1035 & 904 & 856 \\
$\mathrm{Sn}$ & 1.47 & 1.99 & 0.86 & 16.49 & 10.27 & 0.88 & 1.73 & 1.09 & 0.58 & 2.41 & 1.47 & 1.28 & 0.82 & 2.62 \\
$\mathrm{Cu}$ & 52 & 51 & 83 & 43 & 28 & 44 & 57 & 49 & 42 & 73 & 61 & 117 & 93 & 82 \\
$\mathrm{Se}(\mathrm{ppb})$ & $\mathrm{na}$ & na & na & 63 & 140 & na & na & na & na & na & na & na & na & na \\
$\mathrm{Os}$ & $<0,15$ & 0.42 & 0.36 & 0.31 & 0.32 & 0.28 & 0.27 & 0.40 & 0.38 & 0.13 & 0.38 & 0.67 & 0.50 & 0.69 \\
$\mathrm{Ir}$ & 0.04 & 0.54 & 0.50 & 0.47 & 0.56 & 0.44 & 0.46 & 0.55 & 0.54 & 0.66 & 0.50 & 0.79 & 0.67 & 0.87 \\
$\mathrm{Ru}$ & 0.12 & 3.20 & 2.72 & 3.67 & 3.39 & 1.99 & 3.09 & 3.72 & 3.60 & 4.03 & 4.11 & 6.65 & 6.29 & 6.87 \\
$\mathrm{Rh}$ & 0.06 & 1.84 & 1.78 & 1.88 & 1.42 & 1.13 & 1.85 & 2.63 & 1.99 & 3.26 & 2.32 & 4.93 & 3.08 & 4.21 \\
$\mathrm{Pt}$ & $<0,83$ & 20.0 & 23.0 & 18.7 & 12.9 & 12.7 & 12.5 & 76.4 & 9.7 & 23.2 & 9.3 & 14.4 & 11.7 & 15.9 \\
$\mathrm{Pd}$ & 0.47 & 15.4 & 15.8 & 15.4 & 14.3 & 12.5 & 25.6 & 34.7 & 23.5 & 41.2 & 24.6 & 76.9 & 34.2 & 58.0 \\
$\mathrm{Au}$ & $<1,61$ & $<1,61$ & $<1,61$ & 1.00 & 0.75 & 2.87 & $<1,61$ & 4.06 & $<1,61$ & 2.08 & 1.64 & 3.21 & 1.90 & 3.33 \\
${ }^{87 / 86} \mathrm{Sr}_{\mathrm{i}}$ & & & & & 0.70598 & 0.7049 & & & & & & \\
$\delta^{34} \mathrm{~S}$ & & & & & & 0.7056 & & & & & &
\end{tabular}
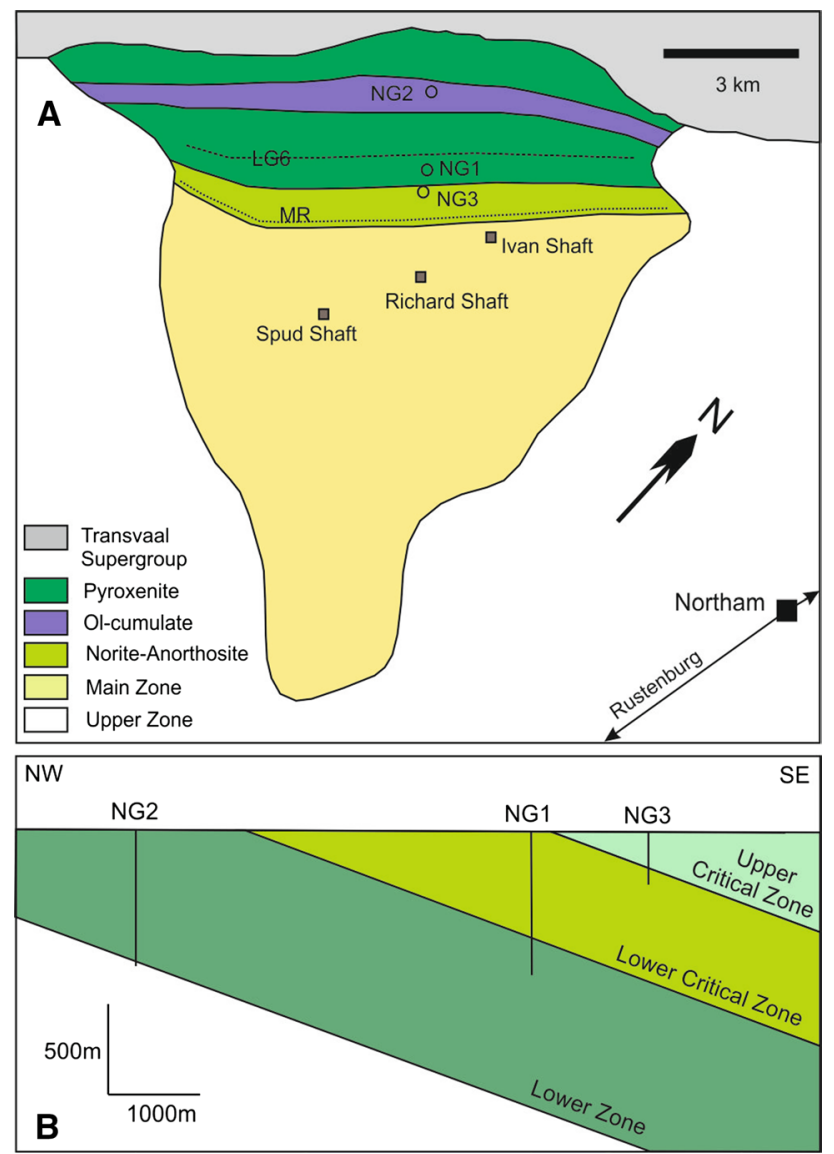

Fig. 2 a Geological map of Union Section, showing location of NG bore holes. b Schematic NW-SE profile indicating orientation of bore holes (modified from Teigler 1990) undulous but sharp, with narrow alteration halos within the harzburgite, suggesting the latter were intruded by the pyroxenites.

\section{Petrography}

The quartzite at the base of the sequence consists of two lithological varieties. The bulk of the rock is banded and locally strongly altered (Fig. 4) consisting of $\sim 80 \%$ fine- to medium-grained quartz grains (up to $0.3 \mathrm{~mm}$ ) in a matrix of predominantly sericite, chlorite and minor hornblende (Fig. 5a). Sulfides increase in abundance toward the contact with the Bushveld Complex; $25 \mathrm{~cm}$ below the contact, the rock contains $1-3 \%$ disseminated pyrrhotite that is pervasively replaced by magnetite. A few $\mathrm{cm}$ from the contact, the sulfide content increases to $>20 \%$, with chalcopyrite having become relatively more abundant. The layers in the quartzite have widths of up to a few millimeters and consist of either relatively quartz-rich, insignificantly altered material or less quartz-rich, but more altered rock. Within the banded quartzite occurs a mass of coarser-grained quartz silicate rock, approximately $10 \mathrm{~cm}$ wide that consists of $\sim 60 \%$ fine-grained (up to $1 \mathrm{~mm}$ ) equigranular quartz grains in a matrix of altered sericite and minor amounts of hornblende. Sulfides occur as very fine disseminations of pyrrhotite, with rare chalcopyrite. In all quartzite varieties, textures are highly equilibrated with $120^{\circ}$ dihedral angles.

The contact between quartzite and the Lower Zone of the Bushveld Complex is transgressive relative to the layering of the quartzite (Fig. 4). The thin sill mentioned above 


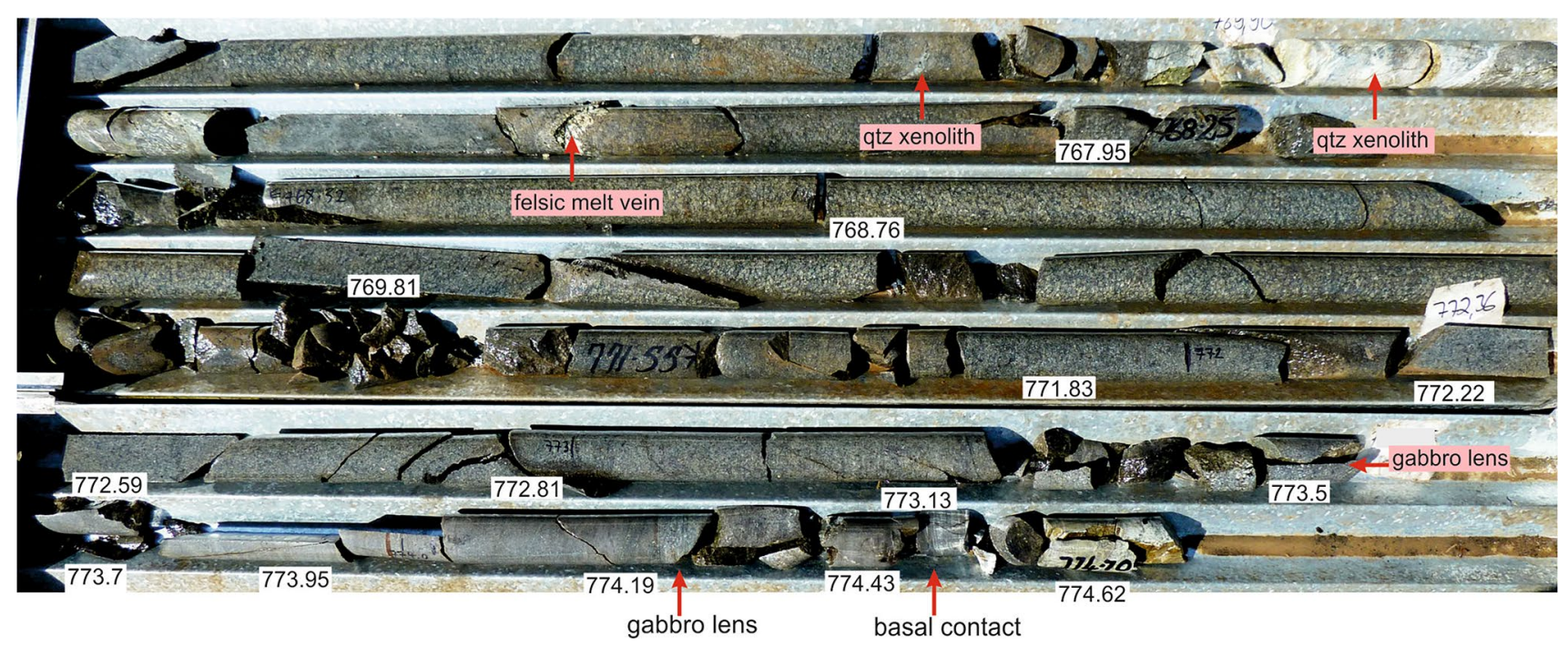

Fig. 3 Basal $8 \mathrm{~m}$ of the NG2 drill core. Note several intervals of broken core possibly indicating faults, the occurrence of several quartzite xenoliths in the upper $2 \mathrm{~m}$ of the sequence, and the basal quartzite underlying the $90 \mathrm{~cm}$ chill sequence

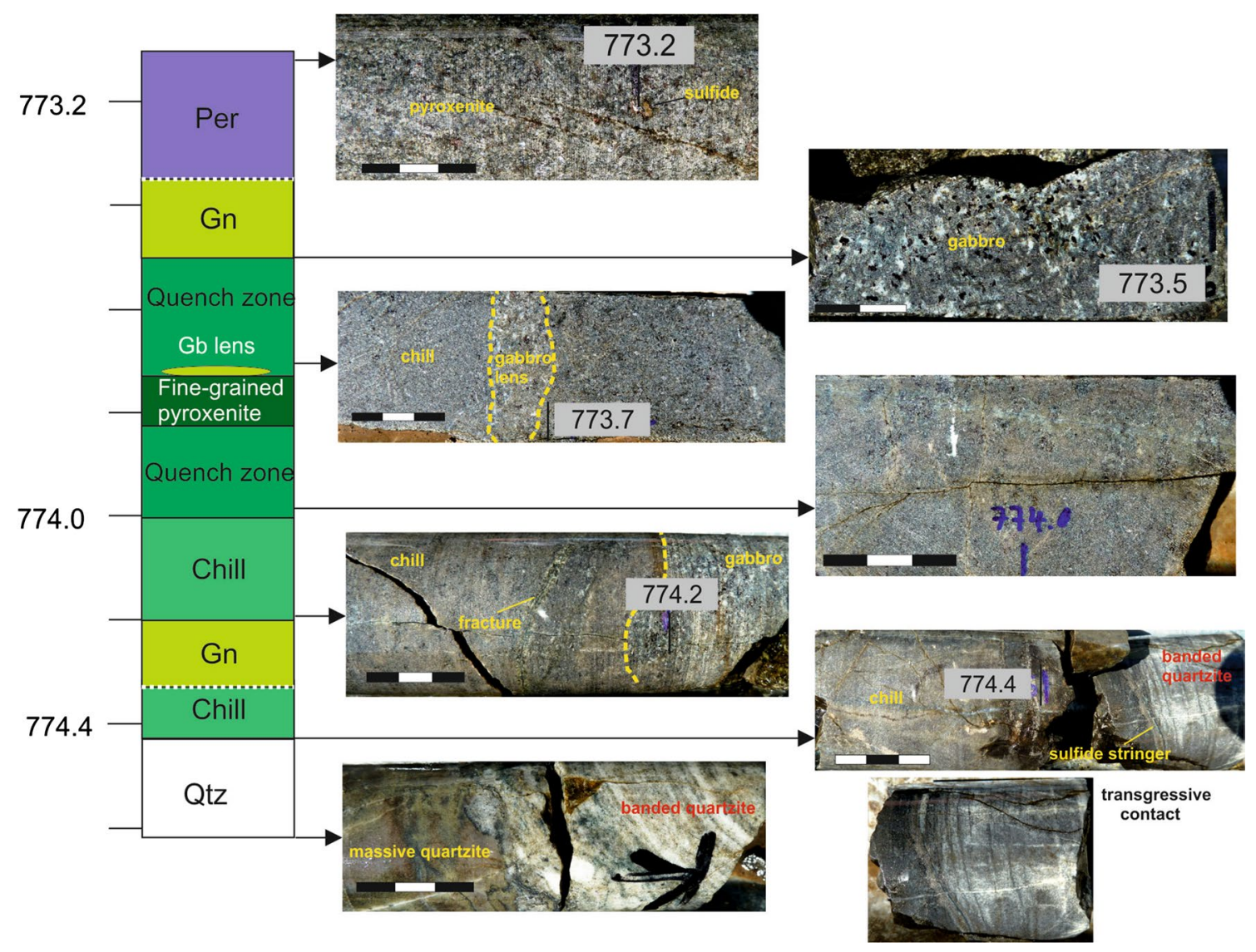

Fig. 4 Stratigraphic log of basal chill sequence in drill core NG2, showing close ups of analyzed samples 

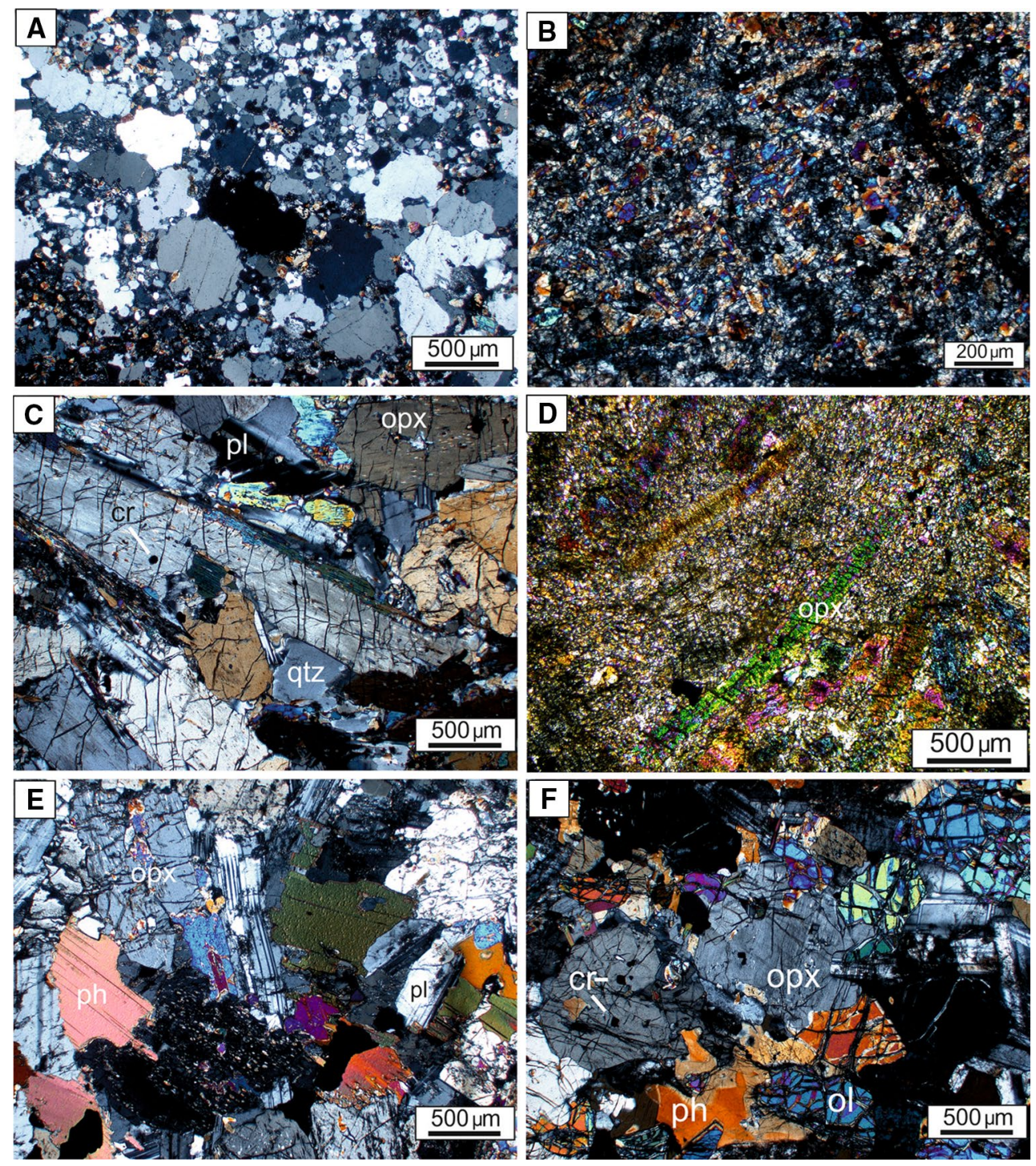

Fig. 5 Silicate petrography of the NG2 chill sequence and the overlying olivine pyroxenites a Banded quartzite, sample NG2 774.62; b Fine-grained chilled margin, sample NG2 774.43; c Lower gabbro lens, NG2 774.31; d Komatiite, sample NG2 773.9; e Upper gabbro lens, sample NG2-773.5; f Olivine orthopyroxenite, sample NG2772.59

The sill is relatively enriched in $\mathrm{Mg}$ (orthopyroxene has $\mathrm{Mg} \#$ 85, as opposed to around 75 in the aphanitic chill). Disseminated sulfides constitute up to 10 modal $\%$ of the rock, forming interstitial masses, mainly of pyrrhotite, with minor chalcopyrite $(<1 \%)$, pentlandite and cubanite. The rock is locally highly altered and replaced by $\mathrm{Ca}-$ Al-rich material, seemingly emanating from sub-vertical veins. Near the base of the sill is a $0.5-1 \mathrm{~mm}$ massive or semi-massive sulfide band, consisting predominantly of pyrrhotite with exsolutions of troilite (Electronic Appendix 3), minor pentlandite and chalcopyrite, and islands of pyrite or marcasite. The sulfide band has mostly sharp lower and upper contacts, but may locally show apophyses into the hostrocks. 
Fig. 6 Element map of sample NG2-774.43, showing basal fine-grained chill of the intrusion (phase 1) hosting thin ultramafic sill (phase 2). In addition, there are several types of sub-vertical veins. See text for explanation

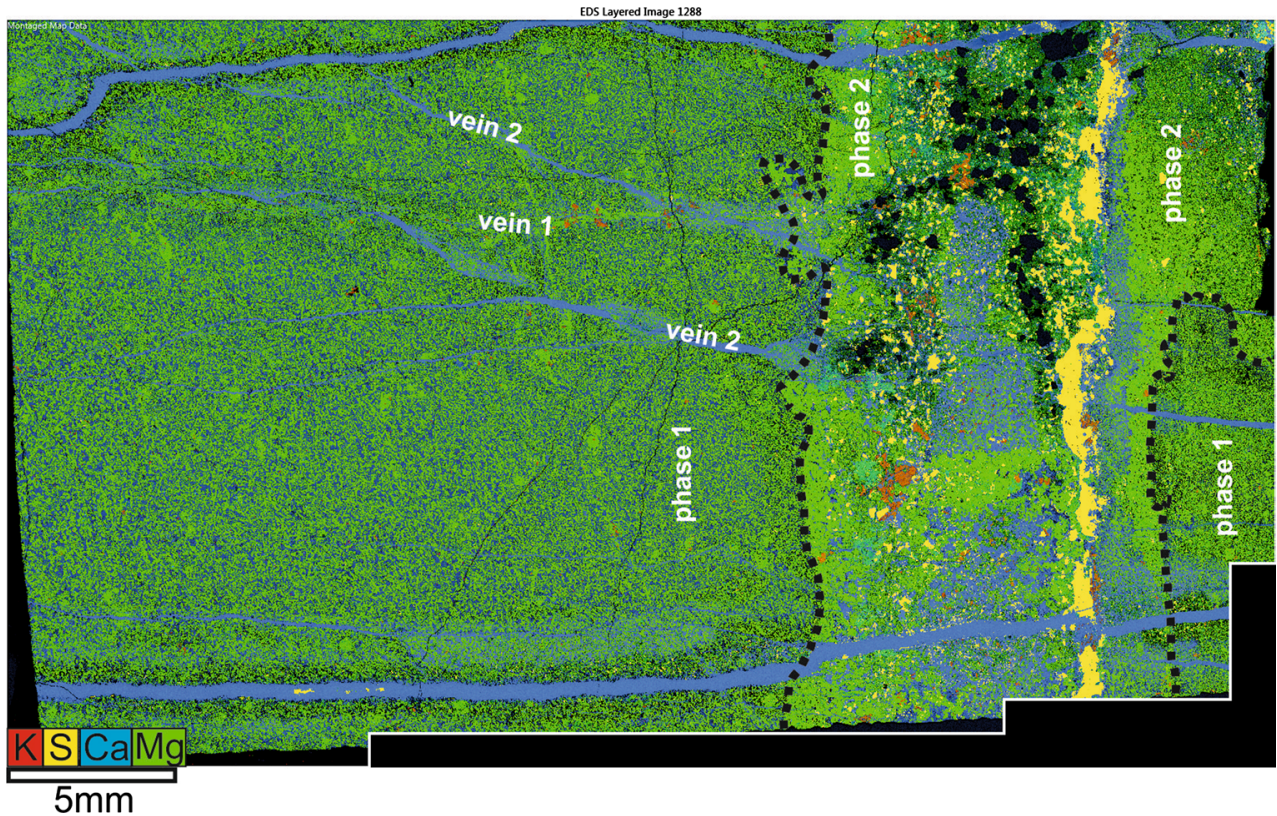

The fine-grained mafic rock overlying the sill consists of small $(<0.5 \mathrm{~mm})$ needles of pyroxene in a matrix of altered material (Fig. 5b), likely a mixture of chlorite, magnetite, and amphibole. The sulfide content is much lower $(\ll 1 \%)$, and the sulfides are much smaller than in the sill, and the proportions of pentlandite and chalcopyrite to pyrrhotite are higher. The $\mathrm{Cr}$ element map revealed very small grains of a Cr-rich phase distributed homogenously throughout the rock, suggesting the magma was chromite saturated. Apart from abundant vertical $\mathrm{Ca}-\mathrm{Al}$ veins discussed below, the rock is homogenous, lacking evidence for, e.g., microxenoliths of quartzite. However, the rock shows a subtle coarsening with height and a decrease in $\mathrm{Mg \#} \mathrm{(Electronic}$ Appendix 2). Whether this is due to fractionation or late stage percolation of $\mathrm{Fe}$ is presently unclear.

Both the chilled rock and the thin sill are crosscut by several generations of sub-vertical veins (Fig. 6). The SEM element maps (Electronic Appendix 2) indicate the presence of Mg-rich veins (Vein type 1) and, more abundantly, $\mathrm{Ca}-\mathrm{Al}$-rich veins (Vein type 2). The latter have distinct growth zones parallel to the walls of the veins suggestive of crystallization from fluids (Electronic Appendix 4). The veins have coronas showing $\mathrm{Si}$ and $\mathrm{Na}$ enrichment (Electronic Appendix 2) indicating several episodes of compositionally contrasting fluid flux, with early $\mathrm{Na}$ (and $\mathrm{Si}$ ) flux and late $\mathrm{Si}, \mathrm{Ca}$ and $\mathrm{Al}$ flux. Associated with the veins are locally elevated concentrations of $\mathrm{S}$ and $\mathrm{K}$, the latter mainly in the $\mathrm{Mg}$-rich veins suggesting post-magmatic $\mathrm{S}$ and $\mathrm{K}$ mobility.

The lower melagabbroic lens located $10 \mathrm{~cm}$ above the base of the intrusion is approximately $10 \mathrm{~cm}$ wide. Its lower contact is not exposed as it is in a zone of broken core. The upper contact is sharp, but undulating. The rock consists of medium-grained, locally highly elongated orthopyroxene (up to $5 \mathrm{~mm}$ in length), a few \% intercumulus clinopyroxene and $\sim 20 \%$ elongated plagioclase laths (up to $2 \mathrm{~mm}$ in length) (Fig. 5c). Quartz and phlogopite are locally abundant, forming large (several mm-wide) intercumulus grains and oikocrysts. A few completely iddingsised olivine grains also occur. Euhedral chromite is an accessory phase, often forming clusters of grains. A number of small zircon grains are mainly included within phlogopite. The sulfides mostly form small interstitial grains of pyrrhotite and minor chalcopyrite locally replacing strongly altered pyroxene.

The melagabbro is overlain by fine-grained melanorite (NG2-774.19) consisting of stubby orthopyroxene mostly $<0.1 \mathrm{~mm}$ in size, but with occasional larger grains of up to $1 \mathrm{~mm}$ in length, in a matrix of fine- to medium-grained $(<0.1-1 \mathrm{~mm})$ cumulus plagioclase.

Next is a rock (NG2-773.95) showing highly elongated, radiating needles of orthopyroxene in a fine-grained matrix. Element mapping suggests that the matrix consists of plagioclase, clinopyroxene, and phlogopite (Figs. 5d, 7). The orthopyroxene can be more than $5 \mathrm{~mm}$ long and, in places, shows hollow cores and other quench textures. Portions of the sample are strongly iddingsised. Sulfides consist of small globular aggregates of pyrrhotite, pentlandite, and chalcopyrite. Based on texture and composition (to be discussed below), this rock is a komatiite (e.g., compare to Fig. 16.6a in Donaldson 1982).

Sample NG2-773.7 is fine- to medium-grained. It has abundant stubby orthopyroxenes, $0.1-0.3 \mathrm{~mm}$ in length, but also contains many larger orthopyroxene grains, $2-3 \mathrm{~mm}$ 
Fig. 7 Element map of komatiite NG2-773.95

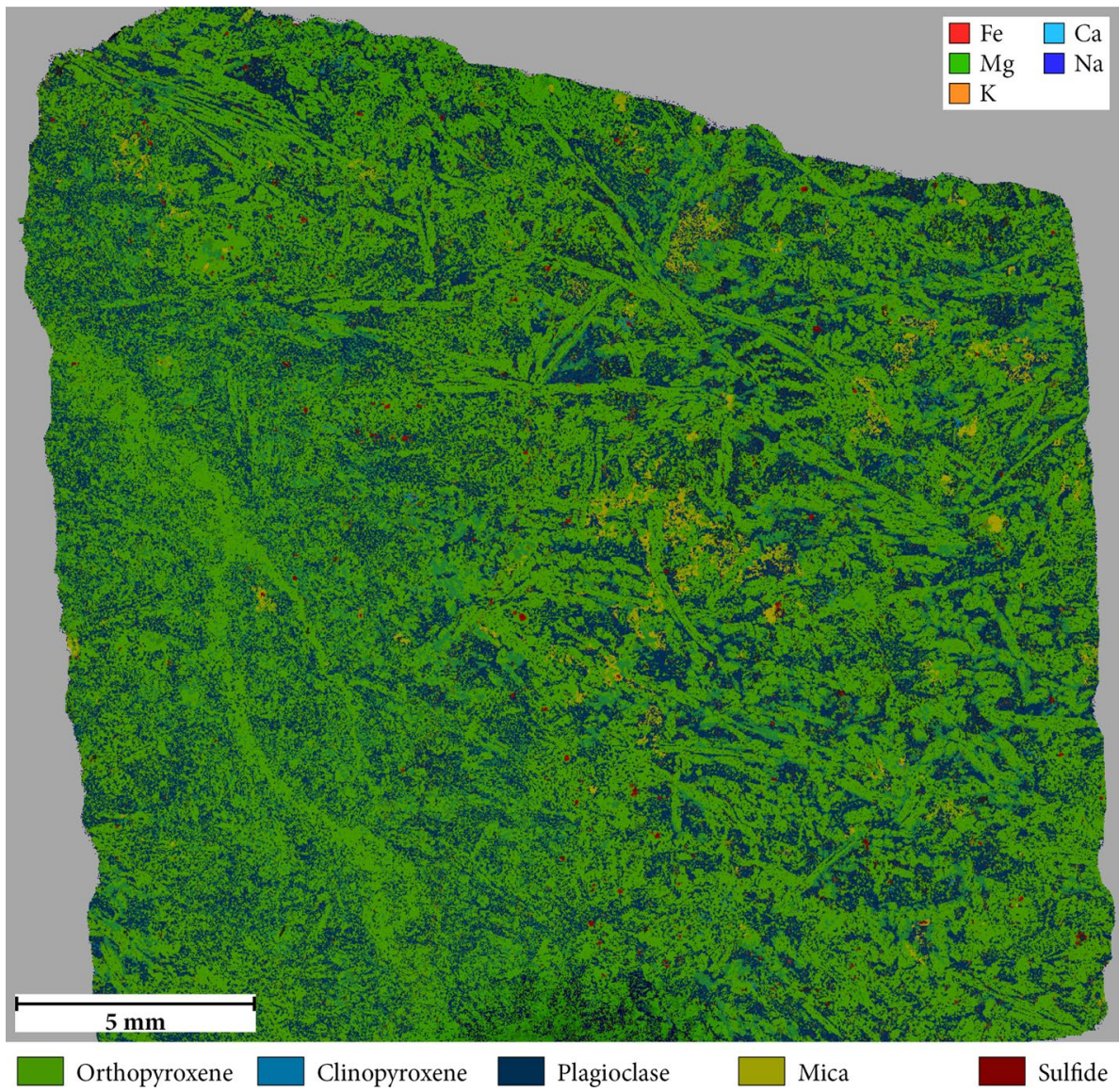

in length. Plagioclase is cumulus and intercumulus and reaches a length of approximately $2 \mathrm{~mm}$.

The upper gabbro lens (773.35-773.5 m, Fig. 5e) consists mainly of medium- to coarse-grained orthopyroxene constituting $50-60 \%$ of the rock and forming elongate crystals up to $1 \mathrm{~cm}$ in length. Large (up to $3 \mathrm{~mm}$ ) phlogopite plates make up $>10 \%$ of the rock. Plagioclase forms cumulus laths with length to width ratios around 2:1. Clinopyroxene is a minor phase $(<5$ modal $\%)$ and forms small cumulus and intercumulus crystals, in addition to exsolution blebs in orthopyroxene. Opaque minerals consist of intercumulus ilmenite and mostly very small disseminations of sulfide ( $\mathrm{Po}, \mathrm{Cp})$, as well as rare larger grains of pentlandite that are partially replaced by magnetite.

The nature of the contact between the pegmatoidal gabbro and the overlying medium-grained olivine pyroxenite (Fig. 5f) that forms the remainder of the analyzed sequence could not be studied as it is in a zone of broken core. The olivine pyroxenite is a medium-grained rock with orthopyroxene-forming anhedral to subhedral crystals up to $3 \mathrm{~mm}$ in width. They contain numerous euhedral, subhedral, and anhedral inclusions of moderately serpentinised olivine, up to approximately $0.5 \mathrm{~mm}$ in width. Some of the grains show hollow cores. The rock has $\sim 10 \%$ phlogopite-forming anhedral interstitial grains up to $\sim 1 \mathrm{~mm}$ in size. Finely disseminated sulfides consist of pyrrhotite, chalcopyrite, and pentlandite, whereas large composite grains consist of pentlandite, pyrrhotite, millerite as well as cubanite and small grains of covellite.

\section{Whole-rock compositions}

\section{Lithophile elements}

The whole-rock composition of the analyzed samples is provided in Table 3, and selected trace elements are plotted in Fig. 8. The chilled basaltic andesites (samples NG2 774.43 and 774.19) have $~ 52.6-53.0 \mathrm{wt} \% \mathrm{SiO}_{2}, 14.7$ $15.7 \% \mathrm{MgO}, 8.8-10.4 \% \mathrm{Al}_{2} \mathrm{O}_{3}, 1170-1240 \mathrm{ppm} \mathrm{Cr}$, and 350-370 ppm Ni (Fig. 8a, b). The concentrations of $\mathrm{MgO}$, $\mathrm{Cr}$, and $\mathrm{Ni}$ are slightly higher, and those of $\mathrm{SiO}_{2}$ and $\mathrm{Al}_{2} \mathrm{O}_{3}$ are lower, than in average $\mathrm{B} 1$ marginal rocks, suggesting that the NG2 basaltic andesite chills crystallized from a less fractionated or less contaminated liquid. The concentrations of immobile incompatible minor and trace elements in the NG2 basaltic andesite chills are $0.23-0.26 \mathrm{wt} \% \mathrm{TiO}_{2}$, 7-32 ppm Zr, 0.14-0.55 ppm Nb, and 0.35-0.69 ppm Th. Many of the incompatible trace elements, as well as Fe, 

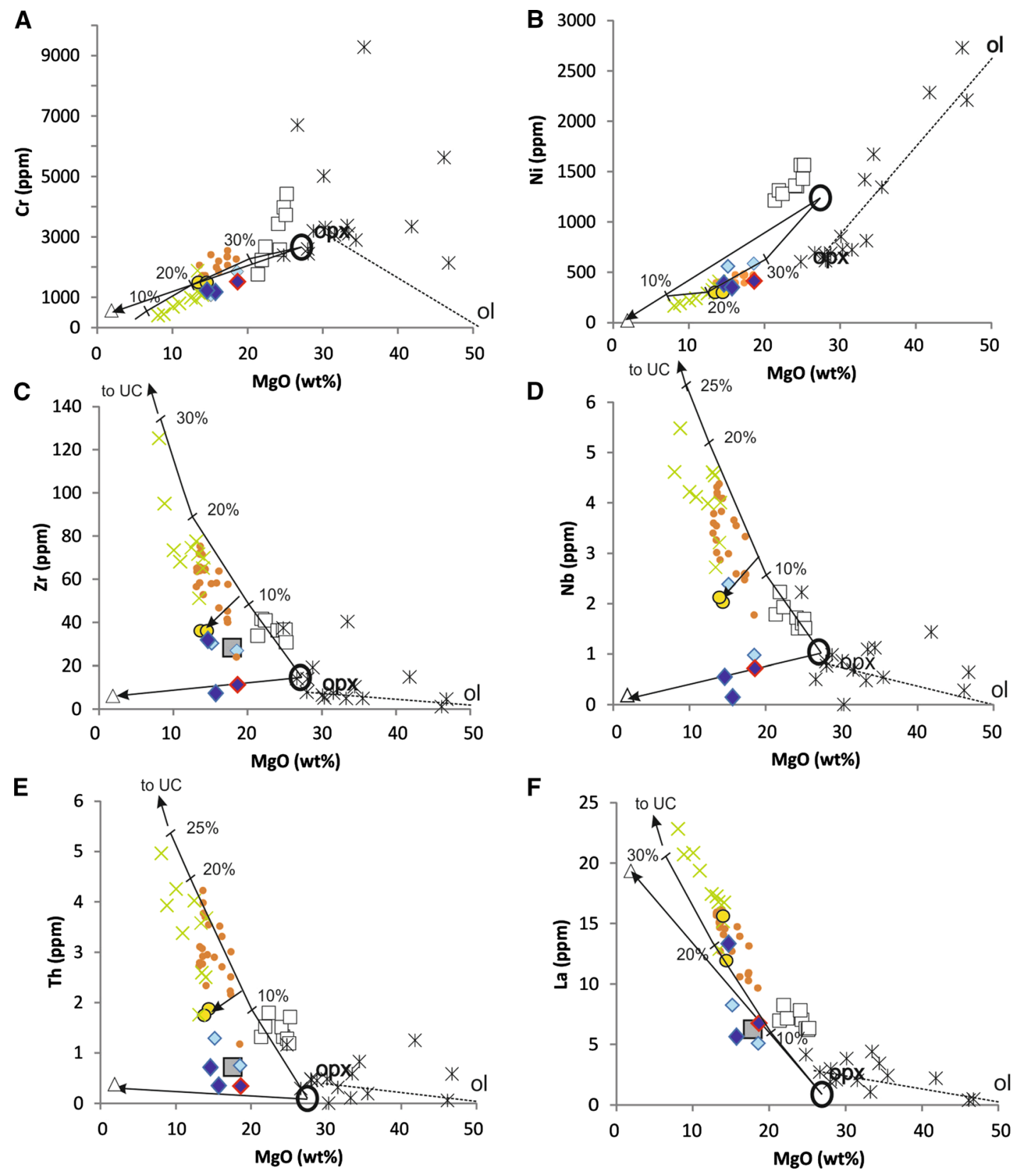

\begin{tabular}{|lllll|}
\hline Basaltic andesite & Medium-grained OI-Px & B1 marginal rocks & \multicolumn{1}{c|}{ Cumulates } \\
NG2-774.43,774.19 & of NG2 chill sequence & $\times$ B1 sills & $\square$ NG2 Ol-Px \\
Komatiite & NG2 773.7, 773.5 & O Clapham chills & $*$ NG2 LZ cumulates & O Komatiite \\
NG2 773.95 & & $\bullet$ Clapham quench & & $\square 20 \%$ SCLM melt \\
\hline
\end{tabular}

Fig. 8 Binary variation diagrams of selected trace elements. The composition of upper crust is from Rudnick and Fountain (1995), except for $\mathrm{Nb}$ (Barth et al. 2000). B1 samples are from Barnes et al. (2010), Clapham samples are from Wilson (2012), komatiite rep- resents median of Al-undepleted komatiites with $<0.3 \% \mathrm{~S}$ from GEOROC. Tielines indicate AFC of upper crust by komatiite, with tick marks denoting proportion of crystallization

incompatible trace elements (11 ppm $\mathrm{Zr}, 0.7 \mathrm{ppm} \mathrm{Nb}$, $0.34 \mathrm{ppm} \mathrm{Th}, 0.27 \mathrm{wt} \% \mathrm{TiO}_{2}$ ). The next sample (NG2773.7) is slightly coarser grained. It has a broadly similar composition as the komatiite, but slightly higher $\mathrm{Cr}$ (1844 ppm) and $\mathrm{Ni}(584 \mathrm{ppm})$ contents, and mostly slightly and $\mathrm{Ni}(412 \mathrm{ppm})$, and has very low concentrations of 


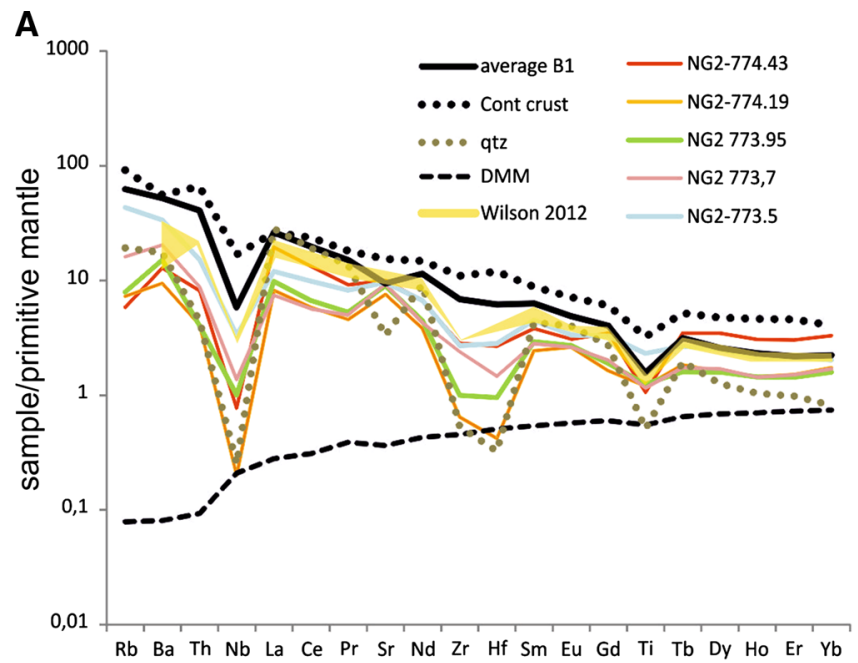

Fig. 9 Primitive mantle-normalized multi-element patterns of a the NG2 chill samples compared to average B1 magma (Barnes et al. 2010), the B1 chill sequence at Clapham (Wilson 2012), the quartzitic floor rock, DMM (Workman and Hart 2005), and upper continental

higher incompatible trace element contents $(27 \mathrm{ppm} \mathrm{Zr}$, $0.98 \mathrm{ppm} \mathrm{Nb}, 0.75 \mathrm{ppm} \mathrm{Th}$ ), with the exception of the LREE. Gabbroic sample NG2-773.5 has broadly similar major and compatible trace elements as the basaltic andesite chill samples, suggesting it also represents a liquid, even though crystal sizes are relatively large. Its incompatible trace elements are generally higher than in the remainder of the chill sequence, though.

In most major and trace element plots, the Bushveld B1 marginal rocks including the present chill sequence and the sills studied by previous authors broadly plot along a mixing line between upper crust and average komatiite. The NG2 chills are most removed from this mixing line toward the quartzitic floor rocks, but several other B1 rocks also show this trend, e.g., the Clapham chills.

The medium-grained olivine pyroxenites overlying the NG2 chilled sequence plot between the wider field of B1 samples and Lower Zone ultramafic rocks suggesting the olivine pyroxenites are orthocumulates with a significant melt component. Plotted against height, they show a progressive increase in $\mathrm{MgO}, \mathrm{Cr}$, and $\mathrm{Ni}$, and a decrease in incompatible elements such as $\mathrm{Zr}$, indicating a progressively higher proportion of cumulus component.

The primitive mantle-normalized incompatible trace element patterns of the NG2 chilled rocks as well as the medium-grained olivine pyroxenites mentioned above show strong negative $\mathrm{Nb}-\mathrm{Ta}$ and, in most cases, $\mathrm{Zr}-\mathrm{Hf}$ and Ti anomalies and relative enrichment in LILE and LREE (Fig. 9a). The patterns show a certain resemblance to those of average B1 magma and average upper crust, but the levels of virtually all elements are markedly lower and the negative $\mathrm{Zr}-\mathrm{Hf}$ anomalies are absent in the $\mathrm{B} 1$ sills.

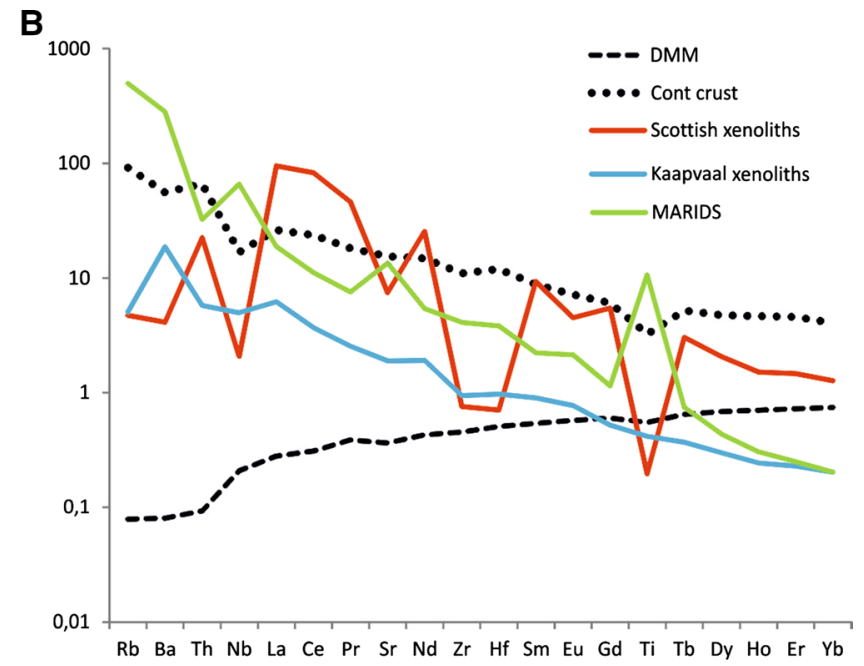

crust (Rudnick and Fountain 1995). b Patterns for Kaapvaal peridotite mantle xenoliths and MARID, as well as xenoliths from Loch Roag, Scotland (Hughes et al. 2014). Normalization factors from Sun and McDonough (1989)

A much better compositional overlap is seen between the NG2 chills and the quartzite floor.

\section{Sr and $S$ isotopes}

Strontium isotopes have so far only be determined in two medium-grained samples from the NG2 chilled sequence (NG2-773.7 and 773.5). Whole-rock initial $\mathrm{Sr}$ isotope ratios are enriched $\left(\mathrm{Sr}_{\mathrm{i}} 0.705-0.706\right)$ relative to the immediately overlying ultramafic Lower Zone rocks ( $\mathrm{Sr}_{\mathrm{i}}$ mostly 0.7045-0.705, Teigler and Eales 1996). In situ sulfur isotopes in spinifex-textured komatiite sample NG2-773.95 are strongly fractionated $\left(\delta^{34} \mathrm{~S}+14.9\right)$, whereas the bulk of the Bushveld layered sequence has $\delta^{34} \mathrm{~S}$ around zero (Liebenberg 1970). These data indicate the presence of a crustal $\mathrm{Sr}$ and $\mathrm{S}$ isotopic component in the chill sequence.

\section{Chalcophile elements}

Sulfur contents of the rocks from the NG2 basal sequence vary from approximately $4000 \mathrm{ppm}$ in the basal sample NG2-774.43 to $300 \mathrm{ppm}$ in gabbroic sample NG2-773.5 at the top of the chill sequence. On average, $\mathrm{S}$ contents in the chill sequence are thus much higher than in B1 (average $<500$ ppm S, Barnes et al. 2009).

The PGE contents in the basal rocks are very similar to B1, at 18-23 ppb Pt and 15-16 ppb Pd (Fig. 10). The highest values occur in the basaltic andesites, followed by the komatiite, and then the medium-grained samples. Compared to magnesian magmas globally, the Pd contents of the B1 suite are at the upper limit of the global data spread, 

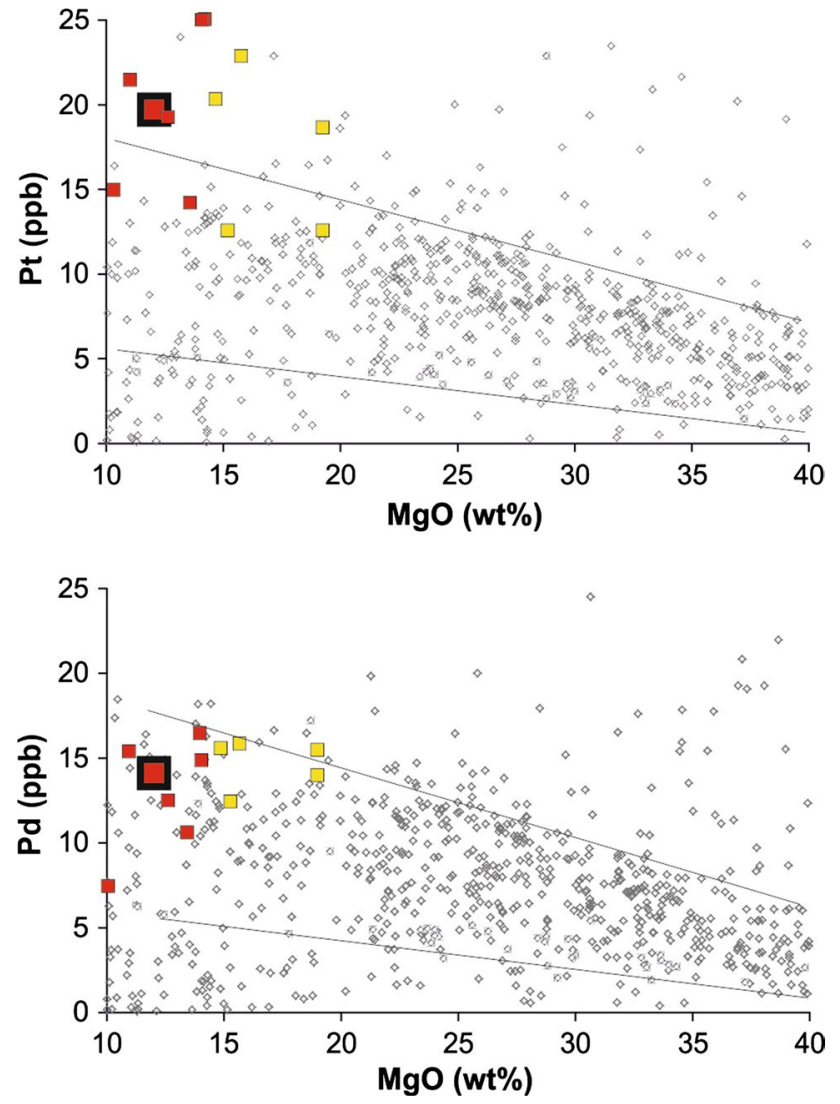

Fig. $10 \mathrm{Pt}$ and Pd contents of Bushveld B1 rocks, compared to komatiitic and basaltic magmas globally (modified from Maier et al. 2009). Red squares denote B1 samples of Barnes et al. (2010), with large red square being the average composition of these samples. Yellow squares represent present NG2 samples

whereas the Pt contents are markedly higher than in the global magmas (see also Barnes et al. 2015). Ratios of Pd/
Ir ( 30) and Pt/Pd (around 1.5), and the shape of the PGE patterns, are identical to $\mathrm{B} 1$ except for the negative $\mathrm{Au}$ anomalies in the NG2 chill sequence (Fig. 11).

Compared to most other Lower Zone cumulates, the medium-grained olivine pyroxenite and harzburgite cumulates directly overlying the chill sequence have relatively high PGE (35-90 ppb), Cu (42-117 ppm) and S contents (760-1035 ppm). The PGE patterns are markedly different from the underlying chill sequence, in that the former are more irregular, with positive $\mathrm{Ru}, \mathrm{Rh}$, and $\mathrm{Pd}$ anomalies and negative $\mathrm{Pt}$ anomalies. Such relatively irregular patterns are typical of cumulate rocks. The rocks also have higher Pd/ Ir ratios than the chilled rocks (40-100) suggesting they crystallized from a relatively more differentiated magma. Of particular note are the relatively low $\mathrm{Pt} / \mathrm{Pd}$ ratios $(<1)$. These are also characteristic of the overlying $300 \mathrm{~m}$ of the Lower Zone, but are otherwise uncommon in the Bushveld Complex, with the exception of the Platreef of the Northern Lobe (Maier et al. 2008; McDonald and Holwell 2011).

\section{Discussion}

The basal contact interval of the Bushveld Complex: a complex sequence of magmatism and hydrothermal veining

The $90 \mathrm{~cm}$ basal contact interval of the Bushveld Complex in drill core NG2 is characterized by a complex suite of intrusive phases consisting of fine- to medium-grained high-Mg basaltic andesite and komatiite, pyroxenite and gabbronorite. Based on textural evidence and compositional arguments, the rocks are interpreted to represent chilled and rapidly cooled liquids. Near its base, the chill
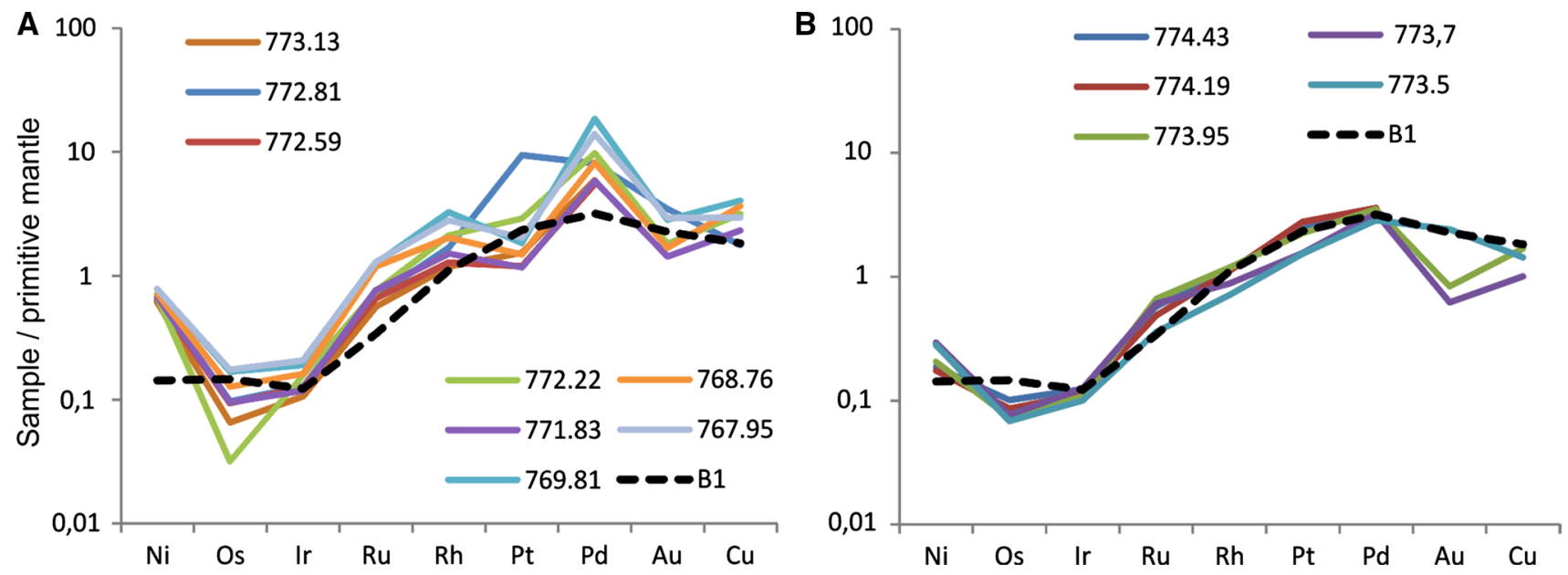

Fig. 11 Primitive mantle-normalized chalcophile element patterns of a olivine pyroxenites overlying the chill sequence, and b NG2 chill sequence. Pattern for B1 magma (data from Barnes et al. 2010) is shown for comparison. Normalization factors from Barnes and Maier (1999) 


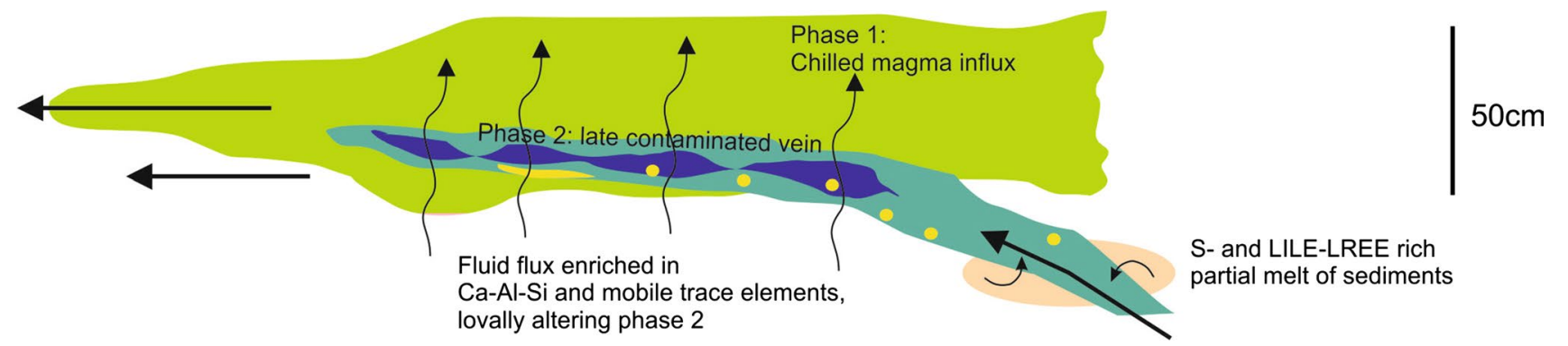

Fig. 12 Schematic model of magma emplacement at the basal contact of the Bushveld Complex

sequence is intruded by a $\sim 1$-cm-wide micro-sill consisting largely of medium-grained orthopyroxene as well as abundant sulfides. Both the chilled rock and the sill are intruded by a swarm of sub-mm, vertical, post-magmatic $\mathrm{Ca}-\mathrm{Al}$ veins (Fig. 12). Element mapping using an SEM indicates that the sill is compositionally distinct from the chilled rock, being markedly enriched in S, K, P-rich phases, and

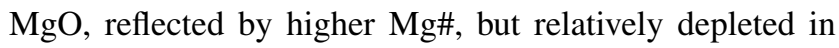
$\mathrm{Al}_{2} \mathrm{O}_{3}$ and $\mathrm{Na}_{2} \mathrm{O}$ (Electronic Appendix 2).

At this stage, we interpret the sill to represent a late injection of crystal-rich magma, either derived from a staging chamber or from remobilized crystal mushes within the Bushveld chamber. The magma had assimilated $\mathrm{S}$ and incompatible elements such as $\mathrm{K}$ and $\mathrm{P}$ from the sedimentary floor rocks. The crosscutting $\mathrm{Ca}-\mathrm{Al}$-rich veins may represent post-magmatic devolatization of the quartzitic floor.

\section{Comparison of the NG2 chills with other Bushveld B1-type marginal rocks}

Until recently, most information on the high-Mg basaltic andesite B1 parent magma to the Lower and Lower Critical Zones of the Bushveld Complex had been gained from the study of fine-grained sills in the floor of the Complex (Davies et al. 1980; Cawthorn et al. 1981; Sharpe 1981; Curl 2001; Barnes et al. 2010). The discovery and study of the Clapham chill sequence in the eastern Bushveld Complex (Wilson 2012) showed for the first time that the chilled margins of the ultramafic rocks of the Bushveld magmatic event also have B1 signatures. The Clapham chill sequence also illustrates the complexity of magma emplacement sequence in the Bushveld, being that it is located at the base of a $700 \mathrm{~m}$ ultramafic sequence (termed the Basal Ultramafic Sequence by Wilson 2012) occurring below the Lower and Marginal zones.

The chill sequence of the NG2 drill core described here is the first such sequence identified at the base of the Lower Zone sensu strictu of the Bushveld Complex. The NG2 chilled and quenched rocks are less evolved than the B1 sills or the Clapham chilled rocks, with 14.7-18.66\%

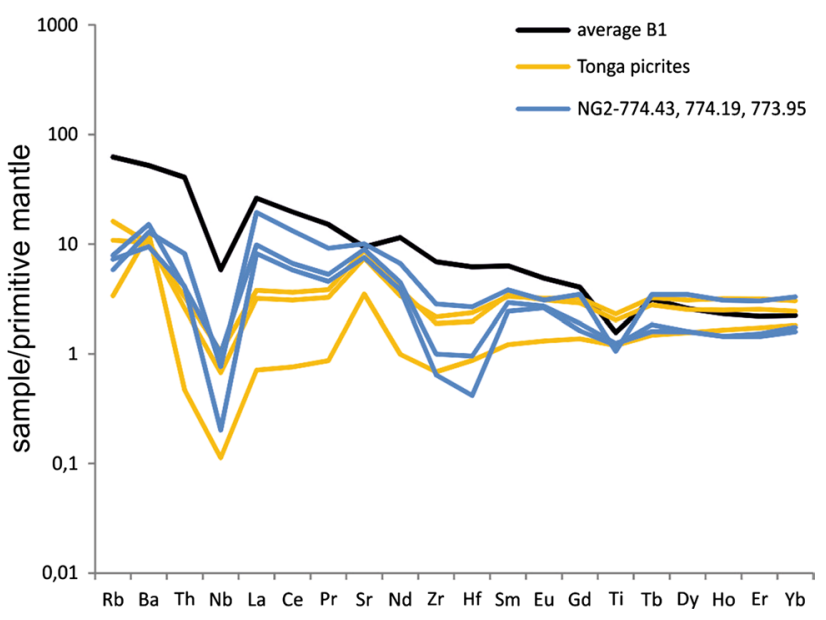

Fig. 13 Comparison of spider patterns for NG2 chills, B1 sills and magnesian basalt from the Tonga arc (Dale et al. 2012)

$\mathrm{MgO}$, higher $\mathrm{Cr}$ and $\mathrm{Ni}$, and lower incompatible trace element contents (Fig. 8). Of particular note are the unusually pronounced depletions of the NG2 chilled samples in HFSE (Fig. 9). The levels of HFSE in the basaltic sample NG2-774.19 are at the level of the depleted MORB mantle (DMM), and the patterns generally resemble those of some arc picrites (Fig. 13). The trace element concentrations are interpreted to be largely of primary magmatic origin as the rocks are relatively unaltered and all chill samples have similar trace element patterns, whereas only sample NG2774.43 contains abundant late $\mathrm{Ca}-\mathrm{Al}$ veins.

In sharp contrast to the relative depletion of the NG2 chills in lithophile trace elements, the PGE contents of the NG chills are nearly identical to the remainder of the B1 suite (Fig. 11). The possible reasons for this contrasting trend of PGE and lithophile trace elements will be discussed in the following chapters.

The scarcity of chilled margins in the Bushveld Complex may reflect poor field exposure of the contact interval and the scarcity of available drill cores; to our knowledge, the NG2 and Clapham drill cores are the only cores that intersect the basal contact, yet both have chill sequences at the base. 


\section{Petrogenesis of the NG2 chilled magma and previously analyzed B1 sill-hosted magmas}

The sill-hosted basaltic andesite Bushveld B1 magmas have previously been interpreted to have formed by two contrasting processes, namely (i) melting of harzburgitic SCLM (Harmer and Sharpe 1985; Maier and Barnes 2004; Richardson and Shirey 2008), and (ii) crustal contamination of asthenosphere-derived komatiite (Barnes 1989; Maier et al. 2000; Wilson 2012). Consensus has remained elusive, mainly because both the above processes may produce similar geochemical signatures in terms of, e.g., $\mathrm{Sr}$ and $\mathrm{Nd}$ isotopes as well as incompatible trace element concentrations. In the following sections, we will use the new data from the NG2 chill sequence to reevaluate the two models.

\section{Magma derivation from the SCLM}

The combination of enriched trace element and $\mathrm{Nd}-\mathrm{Sr}$ isotope signatures, high $\mathrm{Cr}, \mathrm{Ni}$, and $\mathrm{PGE}$ contents and $\mathrm{Pt} / \mathrm{Pd}$ ratios, yet chondritic Os isotope ratios in the Bushveld $\mathrm{B} 1$ marginal rocks was previously interpreted to reflect partial melting of the SCLM by Harmer and Sharpe (1985), Curl (2001), Maier and Barnes (2004), Richardson and Shirey (2008), and Barnes et al. (2010). The unusually elevated Pt contents of Bushveld liquids, in particular, are matched by few other magmas globally (Maier and Barnes 2004; Barnes et al. 2015), yet the resulting high Pt/Pd are similar to those in the SCLM.

A model of SCLM derivation of Bushveld magmas would be consistent with the similarity in incompatible trace element patterns between certain arc picrites and the NG2 chill sequence. Both share negative $\mathrm{Nb}-\mathrm{Ta}$, Ti and $\mathrm{Zr}-\mathrm{Hf}$ anomalies, positive $\mathrm{Sr}$ anomalies, and relative enrichment in LILE and LREE (Fig. 13). The arc picrites tend to lack the high $\mathrm{Pt} / \mathrm{Pd}$ of Bushveld magmas, but this could be explained by the relatively low-P melting regime below arcs during which $\mathrm{Pt}$ behaves in a compatible manner (Mungall and Brenan 2014).

We have simulated partial melting of Kaapvaal SCLM (Maier et al. 2005), using the thermodynamic modeling software MELTS. For the HFSE, LILE, LREE and Pt and $\mathrm{Pd}$, we assumed perfect incompatibility. The results of the modeling are shown in Table 4 (Model 2). At $30 \mathrm{kbar}$, $1557{ }^{\circ} \mathrm{C}$ and $f \mathrm{O}_{2}$ at $\mathrm{QFM}, \mathrm{SiO}_{2}, \mathrm{Fe}$ and $\mathrm{Na}_{2} \mathrm{O}$ levels in the model partial melt are much lower than in the NG2 komatiite, and $\mathrm{Nb}, \mathrm{Ta}, \mathrm{Zr}$, Hf, Th, LREE, $\mathrm{Rb}, \mathrm{Ba}$ and $\mathrm{K}_{2} \mathrm{O}$ are far too high. To explain the high trace element contents, one could suggest that Kaapvaal xenoliths are non-representative of the Kaapvaal SCLM. A recent study on SCLM xenoliths from Scotland (Hughes et al. 2014) indicates the existence of SCLM reservoirs that show relatively high
PGE contents, yet strong negative $\mathrm{Nb}-\mathrm{Ta}, \mathrm{Ti}$ and $\mathrm{Zr}-\mathrm{Hf}$ anomalies. These rocks were interpreted to reflect SCLM metasomatized by carbonatite melts, but their $\mathrm{Nb}$ levels are still too high to explain the composition of the NG2 chills. Foley (2008) showed that $\mathrm{Nb}$ partitions strongly into rutile, and Haggerty (1987) has shown that rutile and other titanates such as lindsleyite and mathiasite that are enriched in $\mathrm{Nb}$ and $\mathrm{Zr}$ are common trace minerals in metasomatized SCLM. Thus, it could be proposed that $\mathrm{Nb}$ and $\mathrm{Zr}$ were effectively fractionated during melting of the Kaapvaal SCLM. However, the problem in applying this model to the Bushveld chills is that carbonatites and nephelinites are low-degree partial melting products which may leave some oxide in the mantle. Bushveld magmas are relatively high-degree melting products (Barnes et al. 2010) and thus oxides are unlikely to remain in the residue. Also, negative $\mathrm{Nb}$ and $\mathrm{Zr}$ anomalies are absent in Kaapvaal GPII kimberlites that are normally assumed to be derived from the SCLM (Becker and Le Roex 2006). Another problem with the SCLM melting model is that our PGE data on kimberlites suggest that the most metasomatized component of the SCLM is very PGE poor $(<1 \mathrm{ppb} \mathrm{Pt}$ and Pd each in more than 25 samples, Maier et al. 2016).

In summary, modeling the komatiite NG2 773.95 via melting of the SCLM provides a poor fit with the data. Furthermore, even if the SCLM melting model were accepted, one would still have to invoke additional crustal contamination to explain the elevated $\mathrm{O}$ isotope ratios of the Bushveld rocks (Harris et al. 2005). Also, critics of the SCLM melting model have questioned whether the relatively cool and refractory SCLM can be significantly molten (Arndt 2013). The MELTS model indicates that the solidus of the most fertile Premier lherzolites is at $1577{ }^{\circ} \mathrm{C}$, whereas the geotherm at the base of the Kaapvaal SCLM was likely much lower. One would thus need to invoke significant conductive heat transfer from the plume into the SCLM.

\section{Crustal contamination of komatiite derived from the convecting mantle}

Generation of the NG2 chills via large-degree melting of the asthenospheric mantle could explain the low HFSE contents, whereas the relatively high LREE contents of the chilled rocks could be due to crustal contamination. The overlap in trace element patterns between the chilled rocks and the quartzitic floor rocks, and the abundance of quartzite xenoliths in the basal $10 \mathrm{~m}$ of the NG2 sequence suggests that the magma could have been contaminated in situ. This model is consistent with the relatively enriched $\delta^{34} \mathrm{~S}$ in the komatiite sample NG2-773.95, the elevated initial $\mathrm{Sr}$ isotope ratios in the medium-grained samples NG2-773.7 and 773.5 , the relatively high sulfide contents in the chill sequence, and the composition of the sulfides; Naldrett 

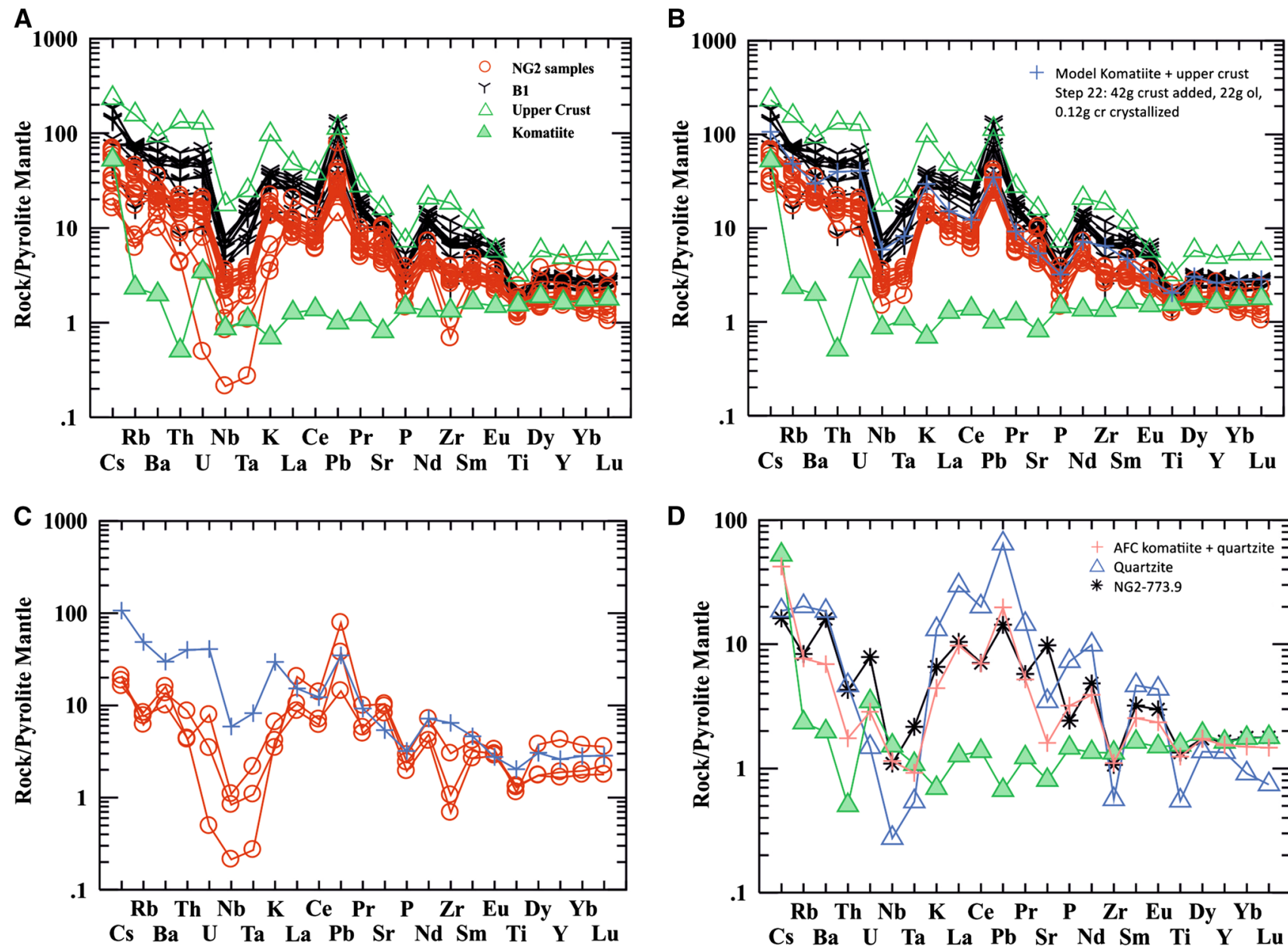

D

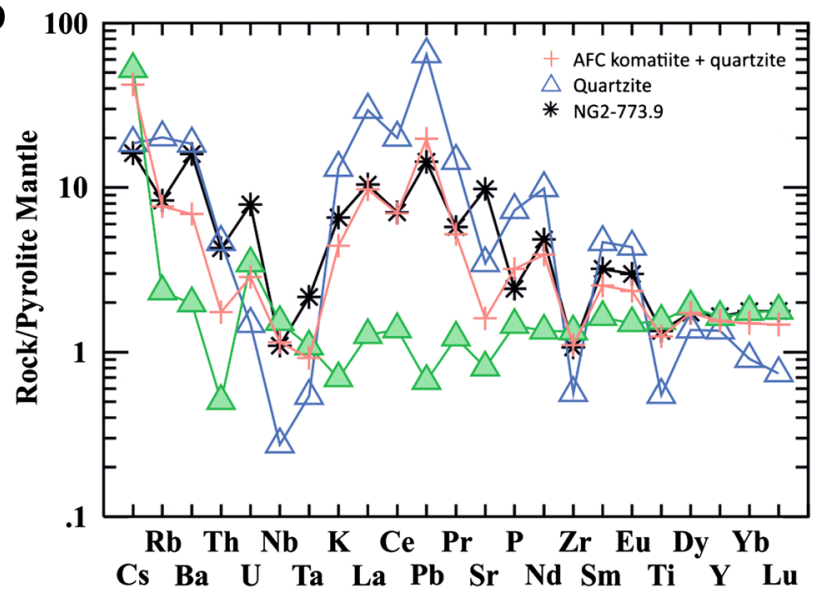

Fig. 14 Modeling of NG2 chilled rocks and B1 magmas. a Primitive mantle-normalized element patterns of NG2 chilled rocks compared to B1 sills (Barnes et al. 2010), average Al-undepleted komatiite from GEOROC (http://georoc.mpch-mainz.gwdg.de/georoc/, and average upper crust (Rudnick and Gao (2003) and Hu and Gao (2008). b AFC (average komatiite $+35 \%$ upper crust $-14 \%$ olivine- $4 \%$

et al. (2000) suggested that the presence of troilite and cubanite, and the absence of pentlandite flames in pyrrhotite may reflect a relatively high $\mathrm{Fe} / \mathrm{S}$ ratio in the sulfide melt, interpreted to result from relatively low $f \mathrm{O}_{2}$, possibly in response to assimilation of graphite.

The bulk of the previously analyzed samples of the B1 suite plot near tielines between UC and average komatiite (Figs. 8c-f; 14) suggesting that these magmas are the products of contamination of komatiite with less trace element-depleted crust than the floor quartzite. A notable exception are the Clapham chills; Like the NG2 chilled rocks, these are also displaced toward quartzite and thus may also have undergone some quartzite contamination. The composition of the primary komatiitic magma remains somewhat unclear. In the present modeling, we used the average of $\sim 1200$ Al-undepleted samples (with $<0.3 \%$

opx) at $3 \mathrm{kbar}$ and $f \mathrm{O}_{2}$ QFM. c NG2 chill samples for which the AFC model of $\mathbf{b}$ is inadequate. $\mathbf{d}$ AFC of average komatiite (3 kbar, QFM) with footwall quartzite (6\% quartzite and $9 \%$ olivine crystallization) showing good overlap with quench-textured komatiite sample NG2 773.95. Normalization factors from McDonough and Sun (1995). See text for further discussion

S) from GEOROC (27\% MgO, $14 \mathrm{ppm} \mathrm{Zr).} \mathrm{Inclusion} \mathrm{of}$ Al-depleted samples makes little difference to the average composition, except for slightly higher $\mathrm{Zr}$. The composition of sample NG2 773.95 has been modeled by AFC using PELE (Boudreau 1999). The model requires bulk assimilation of $6 \%$ quartzite accompanied by $3 \%$ olivine crystallization followed by another $6 \%$ crystallization of olivine without assimilation (Model 3, Table 4).

The B1 sills are far more enriched in incompatible elements, and they can be modeled by AFC using $35 \%$ assimilation of average upper crust (UC) accompanied by $22 \%$ olivine and $5 \%$ orthopyroxene crystallization (Model 4, Table 4). How can the common trend of all B1 samples from UC to a komatiitic end member with about 20-25\% $\mathrm{MgO}$ be explained? One possibility is that the quartz-contaminated komatiite in our chill sequence (NG2 773.95) 
Table 4 Results of modeling

\begin{tabular}{|c|c|c|c|c|c|c|c|c|c|c|c|}
\hline \multirow{2}{*}{ NG2 77} & \multirow{2}{*}{$\begin{array}{l}\text { Target } \\
73.95\end{array}$} & \multicolumn{2}{|l|}{ Model 1} & \multicolumn{3}{|l|}{ Model 2} & \multicolumn{3}{|l|}{ Model 3} & \multirow{2}{*}{$\begin{array}{l}\text { Target } \\
\text { Avg. B1 }\end{array}$} & \multirow{2}{*}{$\begin{array}{l}\text { Model } 4 \\
\text { AFC } 35 \% \\
\text { UC + frac. } \\
\text { of } 22 \% \\
\text { ol }+5 \% \text { opx }\end{array}$} \\
\hline & & $\begin{array}{l}\text { kom }+ \text { zone } \\
\text { ref. } R=1 \\
22 \% \text { frac. } \\
\text { ol }+\mathrm{sp}\end{array}$ & $\begin{array}{l}\text { Rel dif. to } \\
\text { target } \\
\text { model }\end{array}$ & $\begin{array}{l}19 \% \text { Part. } \\
\text { melt of Pre- } \\
\text { mier SCLM }\end{array}$ & $\begin{array}{l}\text { Recalcu- } \\
\text { lated } \\
\text { Anhydrous }\end{array}$ & $\begin{array}{l}\text { Rel dif } \\
\text { to target } \\
\text { model }\end{array}$ & $\begin{array}{l}\text { Komatiite } \\
(+\mathrm{cf} \text { of } 6 \% \\
\text { qtz and } 3 \% \\
\text { ol) }\end{array}$ & $\begin{array}{l}\text { Further cf } \\
\text { of } 6 \% \text { ol }\end{array}$ & Rel dif & & \\
\hline $\mathrm{SiO}_{2}$ & 51.14 & 49.37 & -3 & 45.12 & 47.66 & -7 & 50.29 & 51.89 & 1 & 55.74 & 56.33 \\
\hline $\mathrm{TiO}_{2}$ & 0.27 & 0.43 & 55 & 0.34 & 0.36 & 30 & 0.35 & 0.40 & 45 & 0.34 & 0.54 \\
\hline $\mathrm{Al}_{2} \mathrm{O}_{3}$ & 10.11 & 9.45 & -7 & 10.68 & 11.28 & 12 & 8.11 & 9.50 & -6 & 11.82 & 12.28 \\
\hline $\mathrm{Fe}_{2} \mathrm{O}_{3}$ & 1.11 & 1.41 & 27 & 0.76 & 0.80 & -27 & 1.15 & 1.25 & 13 & 10.50 & 1.09 \\
\hline $\mathrm{FeO}$ & 9.77 & 10.79 & 10 & 8.41 & 8.88 & -9 & 9.12 & 9.43 & -3 & & 7.95 \\
\hline $\mathrm{MnO}$ & 0.23 & 0.25 & 10 & 0.64 & 0.67 & 193 & 0.22 & 0.27 & 17 & 0.18 & 0.19 \\
\hline $\mathrm{MgO}$ & 18.83 & 18.99 & 1 & 18.61 & 19.66 & 4 & 23.03 & 18.28 & -3 & 11.85 & 11.85 \\
\hline $\mathrm{CaO}$ & 6.92 & 8.77 & 27 & 7.15 & 7.55 & 9 & 6.50 & 7.67 & 11 & 6.50 & 6.79 \\
\hline $\mathrm{Na}_{2} \mathrm{O}$ & 0.87 & 0.45 & -48 & 0.05 & 0.06 & -94 & 0.28 & 0.33 & -62 & 1.63 & 1.55 \\
\hline $\mathrm{K}_{2} \mathrm{O}$ & 0.19 & 0.19 & 3 & 2.61 & 2.75 & 1369 & 0.57 & 0.67 & 258 & 0.98 & 1.23 \\
\hline $\mathrm{P}_{2} \mathrm{O}_{5}$ & 0.03 & 0.09 & 199 & 0.21 & 0.22 & 650 & 0.09 & 0.09 & 213 & 0.08 & 0.09 \\
\hline $\mathrm{H}_{2} \mathrm{O}$ & 0.14 & & & 5.32 & & & 0.05 & & & 0.31 & \\
\hline $\mathrm{S}$ & 0.08 & 0.04 & 50 & & & & 0.041 & 0.047 & 15 & & \\
\hline $\mathrm{Ru}$ & 3.67 & 3.04 & -17 & 3.67 & 3.88 & 6 & 0.81 & 0.48 & -87 & 1.90 & 3.37 \\
\hline $\mathrm{Pd}$ & 15.42 & 15.59 & 1 & 14.14 & 14.93 & -3 & 8.79 & 10.30 & -33 & 14.00 & 8.21 \\
\hline $\mathrm{Sc}$ & 33 & 31 & -8 & 16 & 16 & -51 & 23 & 25 & -24 & 29 & 25 \\
\hline V & 146 & 173 & 19 & 135 & 142 & -2 & 135 & 152 & 4 & 164 & 157 \\
\hline $\mathrm{Cr}$ & 1514 & 1094 & -28 & 718 & 758 & -50 & 2404 & 1386 & -8 & 965 & 1898 \\
\hline $\mathrm{Co}$ & 52 & 53 & 0 & 39 & 41 & -22 & 86 & 61 & 16 & 59 & 71 \\
\hline $\mathrm{Ni}$ & 412 & 91 & -78 & 285 & 301 & -27 & 884 & 214 & -48 & 284 & 374 \\
\hline $\mathrm{Zn}$ & 108 & 79 & -26 & 52 & 55 & -49 & 74 & 76 & -30 & 80 & 93 \\
\hline $\mathrm{Rb}$ & 5 & 2 & -52 & 110 & 116 & 2223 & 6 & 7 & 33 & 40 & 42 \\
\hline $\mathrm{Sr}$ & 195 & 72 & -63 & 426 & 450 & 131 & 28 & 32 & -84 & 198 & 151 \\
\hline $\mathrm{Y}$ & 7.09 & 9.37 & 32 & 7.03 & 7.43 & 5 & 8.51 & 9.95 & 40 & 11.67 & 14.66 \\
\hline $\mathrm{Zr}$ & 11.16 & 18.74 & 68 & 27.25 & 28.78 & 158 & 15.05 & 17.56 & 57 & 77.04 & 94.50 \\
\hline $\mathrm{Nb}$ & 0.72 & 1.34 & 87 & 18.07 & 19.09 & 2565 & 1.00 & 1.17 & 63 & 4.15 & 5.46 \\
\hline Cs & 0.34 & 0.80 & 133 & 2.24 & 2.37 & 589 & 0.71 & 0.82 & 139 & 2.55 & 0.74 \\
\hline $\mathrm{Ba}$ & 105.49 & 183.33 & 74 & 1421.79 & 1501.70 & 1324 & 50.47 & 58.53 & -45 & 363.95 & 279.75 \\
\hline $\mathrm{La}$ & 6.75 & 6.49 & -4 & 6.60 & 6.97 & 3 & 7.49 & 8.78 & 30 & 18.00 & 14.03 \\
\hline $\mathrm{Ce}$ & 11.81 & 11.21 & -5 & 13.19 & 13.93 & 18 & 13.74 & 16.11 & 36 & 34.80 & 28.95 \\
\hline $\mathrm{Nd}$ & 6.04 & 5.47 & -9 & 7.09 & 7.49 & 24 & 2.87 & 3.36 & -44 & 15.47 & 12.57 \\
\hline $\mathrm{Sm}$ & 1.30 & 1.36 & 5 & 1.73 & 1.83 & 41 & 1.27 & 1.40 & 8 & 2.80 & 2.56 \\
\hline $\mathrm{Eu}$ & 0.46 & 0.46 & 1 & 0.60 & 0.63 & 39 & 0.41 & 0.47 & 3 & 0.82 & 0.62 \\
\hline $\mathrm{Gd}$ & 1.12 & 1.34 & 19 & 1.79 & 1.89 & 68 & 1.48 & 1.73 & 54 & 2.40 & 2.53 \\
\hline $\mathrm{Tb}$ & 0.17 & 0.25 & 45 & 0.24 & 0.25 & 47 & 0.25 & 0.29 & 68 & 0.34 & 0.45 \\
\hline Dy & 1.17 & 1.70 & 45 & 1.45 & 1.53 & 31 & 1.50 & 1.76 & 50 & 1.90 & 2.70 \\
\hline Ho & 0.24 & 0.37 & 56 & 0.33 & 0.35 & 47 & 0.32 & 0.37 & 56 & 0.38 & 0.58 \\
\hline Er & 0.69 & 1.07 & 55 & 0.79 & 0.83 & 21 & 0.91 & 1.07 & 55 & 1.05 & 1.63 \\
\hline $\mathrm{Tm}$ & 0.11 & 0.16 & 48 & 0.09 & 0.10 & -12 & 0.13 & 0.15 & 38 & 0.16 & 0.26 \\
\hline $\mathrm{Yb}$ & 0.78 & 1.03 & 32 & 4.34 & 4.58 & 486 & 0.85 & 0.99 & 27 & 1.10 & 1.63 \\
\hline $\mathrm{Lu}$ & 0.12 & 0.16 & 29 & 0.09 & 0.10 & -23 & 0.13 & 0.15 & 21 & 0.17 & 0.25 \\
\hline $\mathrm{Hf}$ & 0.29 & 0.59 & 100 & 0.48 & 0.51 & 72 & 0.44 & 0.51 & 73 & 1.91 & 2.64 \\
\hline $\mathrm{Ta}$ & 0.08 & 0.05 & -36 & 0.96 & 1.01 & 1197 & 0.04 & 0.05 & -36 & 0.48 & 0.43 \\
\hline $\mathrm{Pb}$ & 2.15 & 2.50 & 16 & 9.07 & 9.58 & 345 & 2.91 & 3.39 & 58 & 13.92 & 7.46 \\
\hline Th & 0.34 & 0.67 & 95 & 0.81 & 0.86 & 150 & 0.17 & 0.20 & -42 & 3.46 & 4.56 \\
\hline
\end{tabular}


Table 4 continued

\begin{tabular}{|c|c|c|c|c|c|c|c|c|c|c|c|}
\hline \multirow{2}{*}{ NG2 } & \multirow{2}{*}{$\begin{array}{l}\text { Target } \\
773.95\end{array}$} & \multicolumn{2}{|l|}{ Model 1} & \multicolumn{3}{|l|}{ Model 2} & \multicolumn{3}{|l|}{ Model 3} & \multirow{2}{*}{$\begin{array}{l}\text { Target } \\
\text { Avg. B1 }\end{array}$} & \multirow{2}{*}{$\begin{array}{l}\text { Model } 4 \\
\text { AFC } 35 \% \\
\text { UC }+ \text { frac. } \\
\text { of } 22 \% \\
\text { ol }+5 \% \text { opx }\end{array}$} \\
\hline & & $\begin{array}{l}\text { kom }+ \text { zone } \\
\text { ref. } R=1 \\
22 \% \text { frac. } \\
\text { ol }+\mathrm{sp}\end{array}$ & $\begin{array}{l}\text { Rel dif. to } \\
\text { target } \\
\text { model }\end{array}$ & $\begin{array}{l}19 \% \text { Part. } \\
\text { melt of Pre- } \\
\text { mier SCLM }\end{array}$ & $\begin{array}{l}\text { Recalcu- } \\
\text { lated } \\
\text { Anhydrous }\end{array}$ & $\begin{array}{l}\text { Rel dif } \\
\text { to target } \\
\text { model }\end{array}$ & $\begin{array}{l}\text { Komatiite } \\
(+\mathrm{cf} \text { of } 6 \% \\
\text { qtz and } 3 \% \\
\text { ol) }\end{array}$ & $\begin{array}{l}\text { Further cf } \\
\text { of } 6 \% \text { ol }\end{array}$ & Rel dif & & \\
\hline$\overline{\mathrm{U}}$ & 0.16 & 0.32 & 99 & 0.20 & 0.21 & 31 & 0.08 & 0.08 & -50 & 0.99 & 1.20 \\
\hline $\mathrm{Rh}$ & 1.88 & 1.54 & -18 & 2.00 & 2.11 & 12 & 0.37 & 0.94 & -50 & 1.78 & 0.80 \\
\hline Os & 0.31 & 0.90 & 192 & 1.58 & 1.67 & 441 & 1.77 & 1.51 & 390 & 0.50 & 1.04 \\
\hline $\mathrm{Ir}$ & 0.47 & 0.90 & 91 & 1.94 & 2.05 & 335 & 1.33 & 1.17 & 149 & 0.54 & 0.78 \\
\hline $\mathrm{Pt}$ & 18.69 & 19.23 & 3 & 21.10 & 22.29 & 19 & 8.93 & 10.42 & -44 & 19.36 & 8.61 \\
\hline $\mathrm{Au}$ & 1.00 & 3.46 & 246 & 2.08 & 2.20 & 120 & 1.96 & 2.29 & 129 & 2.72 & 1.63 \\
\hline $\mathrm{Cu}$ & 47.50 & 51.28 & 8 & 50.85 & 53.71 & 13 & 42.44 & 49.17 & 4 & 50.73 & 31.64 \\
\hline
\end{tabular}

is parental to all B1 samples, with the latter additionally assimilating the roof rocks of a progressively inflating chamber. However, we see the same trace element and $\mathrm{Nd}$ isotope ratios as in the B1 suite in chilled margins of the Uitkomst complex (Maier et al., submitted), suggesting that the bulk of the B1 suite assimilated UC at the base of, or below the Transvaal Supergroup. We thus favor a model whereby all B1 samples are derived from an uncontaminated parent komatiite with around $20-25 \% \mathrm{MgO}$. Those B1 magmas forming the sills assimilated shale or granite in a staging chamber, whereas the B1 magma parental to the NG2 chills escaped the contamination in the staging chamber, but instead assimilated quartzite floor upon final emplacement at the level of the Bushveld chamber.

The main problem with the above model is that the NG2 chills have among the highest $\mathrm{Pt}$ contents (and $\mathrm{Pt} / \mathrm{Pd}$ ratios) of global magmas, yet most crustal lithologies are relatively PGE poor (average of 1.5-2 ppb Pt and Pd each, Schmidt et al. 1997). Thus, addition of average lower or upper crust, or the quartzitic footwall rocks $(<1 \mathrm{ppb} \mathrm{Pt}+\mathrm{Pd}$, Table 3$)$ to komatiite (typically having $<10 \mathrm{ppb} \mathrm{Pt}$ and $\mathrm{Pd}$, Fiorentini et al. 2011) would not result in the observed PGE enrichment, in particular Pt.

Several potential explanations can be considered. Firstly, the parent komatiite could have assimilated unusually PGE-rich crust prior to final emplacement. Crustal lithologies rich in PGE and with high Pt/Pd include some black shales (Jowitt and Keays 2012), Mn nodules (Balaram et al. 2006), and certain meteorite spherule layers (Simonson and Glass 2004). However, these PGE-rich lithologies tend to form relatively minor components of the crust. Shales enriched in PGE, e.g., in China, form horizons a few $\mathrm{dm}$ in thickness (Jowitt and Keays 2012). Most impact spherule layers are even thinner. Horizons markedly enriched in Mn have so far not been described from the Transvaal sedimentary rocks hosting the Bushveld Complex. Wille et al. (2007) found an average of $\sim 8 \mathrm{ppb} \mathrm{Pt}$ and Pd each in four samples of Timeball Hill and Silverton shale, and only slightly lower average values in the predominantly dolomitic Ghaap Group. Assimilation of such crust would dramatically reduce the PGE mass balance problem, but the model of contamination of komatiite with Transvaal Supergroup rocks is inconsistent with other isotope and trace element data; For example, chromite separates in the B1 sills (that have equally high PGE contents as the NG2 chills) have near-chondritic Os isotope ratios (Curl 2001), as have some of the chromitite seams in the Bushveld Lower Zone (Schönberg et al. 1999), whereas the Transvaal sedimentary rocks have relatively high Os contents $(0.44 \mathrm{ppb}$ on average) and ${ }^{187 / 188}$ Os ratios (Wille et al. 2007), resulting in $\gamma \mathrm{Os}(2050 \mathrm{Ma})$ up to +1800 . Assimilation of even small amounts of such crust would result in high yOs of the B1 magma. Contamination of komatiite with granite gneiss basement or lower crustal granulite does not offer a solution to the PGE deficiency in the AFC model as these reservoirs also tend to be relatively PGE poor (Hart et al. 2003). Also, if the PGE were derived from assimilation of felsic crust, one would expect to see a correlation between PGE contents and other evolved components, which is not observed (Electronic Appendix 6). Another potentially Ptrich crustal reservoir is ultramafic cumulates (e.g., Maier et al. 2015), but such rocks tend to be relatively refractory and are thus unlikely to have been significantly assimilated by the Bushveld magmas.

Secondly, PGE could have been extracted from the SCLM and added to komatiite during impingement of the mantle plume at the base of the SCLM (Model 1, Table 4). Palladium is largely held within the intercumulus material of the SCLM (Alard et al. 2000), whereas Pt may be held in Pt alloys, either interstitially or included within olivine. Mungall and Brenan (2014) have shown that Pt solubility is enhanced at relatively high pressure below thick SCLM keels, and one could thus suggest that the heat of the plume could partially melt the SCLM by a process analogous to 
zone refining. This could efficiently extract the PGE from the SCLM, thereby enriching the plume magma. The problem with this model is that the plume magma should also have assimilated other fusible components of the SCLM, increasing, e.g., the $\mathrm{Nb}$ and $\mathrm{Zr}$ contents of the magma, unless $\mathrm{Nb}$ and $\mathrm{Zr}$ behave compatibly during melting of SCLM (see discussion in previous chapter). Another problem pointed out above is that the metasomatized, relatively fusible component of the SCLM appears to be PGE poor.

Thirdly, the plume magma could have attained sulfide saturation in a holding chamber, leading to the formation of small sulfide droplets. The sulfides collected PGE and some droplets were transported with the magma. During continued magma ascent, the sulfides were progressively resorbed due to the decrease in pressure. As Pt tends to form alloys during sulfide resorption whereas Pd is dissolved in the silicate liquid (Peregoedova et al. 2006), this process can lead to fractionation of $\mathrm{Pt}$ from $\mathrm{Pd}$. The B1 magmas may be relatively enriched in dissolved Pt alloys, leading to the observed high Pt content. One difficulty is that the B1 sills of Curl (2001) have too little S (400 ppm) to trigger sulfide melt saturation even at high pressure, so one would have to add to the argument the idea that $\mathrm{S}$ was lost from B1 after emplacement. However, S/Se ratios of the B1 rocks are mantle like (Barnes et al. 2009) and thus do not support this model unless Se is lost with S. Another problem is that the process should also result in Pd-rich magmas, which are rare in the Bushveld magmatic province.

Fourthly, prior to crustal contamination the B1 suite could have formed from an unusually PGE-rich komatiitic parent liquid, derived from a mantle plume that contained material enriched in late veneer or derived from the Earth's outer core (Brandon et al. 1998, Maier et al. 2009; Humayun 2011). This model provides the best fit with the observed data and is currently favored by us. A potential test would be to determine $\mathrm{Cr}$ isotopes in fractionated $\mathrm{Cr}$ poor) residual melts of the $\mathrm{B} 1$ magmas.

\section{Origin of high-Fo olivine in Bushveld and Uitkomst intrusions}

Wilson (2012) identified relatively forsteritic olivine (Fo up to 90.8 ) in a $8-\mathrm{m}$ dunitic layer located immediately above the chilled margin at Clapham in the eastern Bushveld Complex. Even more unevolved olivine had previously been identified in the Lower Zone of the Northern Lobe, at Grasvally (Hulbert and von Gruenewaldt 1982), and subsequently at Turfspruit and Sandsloot (Yudovskaya et al. 2013), and in the Uitkomst Complex (Gauert et al. 1995; $\mathrm{Li}$ et al. 2002) that also forms part of the Bushveld event. Wilson (2012) argued that the Clapham olivines originally had Fo contents of around 93 followed by reequilibration with trapped melt and thus originally crystallized from a komatiitic magma with approximately $19 \mathrm{wt} \% \mathrm{MgO}$. No komatiitic liquids were identified, though, with the chill at the base of the Clapham sequence having $14 \mathrm{wt} \% \mathrm{MgO}$, in the range of most other B1 sills. It could be argued that the high-Fo olivine crystallized from the parent magma to the NG2 komatiite (NG2 773.95) prior to contamination of the latter with footwall quartzite. However, the high-Fo Clapham dunites have similar $\mathrm{La} / \mathrm{Sm}$ and $\mathrm{La} / \mathrm{Nb}$ as other LZ cumulates (Wilson 2012) and B1 (La/Sm 5.6-7.3, La/ $\mathrm{Nb}$ 3.7-4.9; Barnes et al. 2010), and far higher ratios than typical komatiite $(\mathrm{La} / \mathrm{Sm} 1.2, \mathrm{La} / \mathrm{Nb} 1.4)$. We thus argue that the high-Fo olivines at Clapham (and possibly those at Grasvally, Turfspruit and Sandsloot) did not crystallize from komatiite but from normal B1 that, in addition to contamination in a staging chamber with sub-Transvaal Supergroup rocks, was also contaminated with dolomitic floor rocks. Dolomite is relatively poor in REE, and thus, the contamination would not significantly alter trace element ratios. Dolomite assimilation is evident at Turfspruit, Sandsloot, and Uitkomst, in the form of abundant xenoliths of dolomite. At all three localities, dolomite forms an important component of the floor rocks. Wilson (2012) does not mention any evidence for dolomitic contamination in the Clapham sequence, but dolomite xenoliths occur nearby, e.g., in the Marginal Zone on the farm Hendriksplaas, to the $\mathrm{N}$ of Steelpoort.

Two possible models may be considered of how dolomite assimilation could have caused high-Fo contents in olivine. (i) Devolatization of dolomite could have oxidized the magma via release of $\mathrm{CO}_{2}$ (Wenzel et al. 2002). (ii) Melting of dolomite, triggered by locally elevated $\mathrm{H}_{2} \mathrm{O}$ contents, could have led to high concentrations of $\mathrm{MgO}$ in the magma. Both models would explain the relatively low $\mathrm{Ni}$ content in some of the high-Fo olivines (Wilson 2012). Model (ii) would be consistent with the fact that the contaminated intervals at Uitkomst and in the Northern lobe tend to be relatively enriched in clinopyroxene (Gauert et al. 1995; McDonald and Holwell 2011). However, as yet there is no evidence of elevated Ca contents in Bushveld olivine, analogous to the olivines analyzed by Wenzel et al. from the Joko Dovyren intrusion. Further work is in progress to constrain the origin of the high-Fo olivine at Uitkomst and in the northern lobe of the Bushveld Complex.

\section{Summary and conclusions}

The present study documents the first example of a chilled margin at the base of the Lower Zone of the Bushveld Complex. The base of the chill sequence has been injected by a microsill and small $\mathrm{Ca}-\mathrm{Al}$ veins, demonstrating that the interpretation of chilled margins of intrusions requires detailed examination. 
The chill sequence contains Mg-rich basaltic andesite and komatiite. The rocks have ultralow HFSE contents, but are relatively enriched in LREE and LILE, and have elevated $\mathrm{Sr}_{\mathrm{i}}$ and $\delta^{34} \mathrm{~S}$. Together with the abundance of quartzite xenoliths, this suggests that the parent magmas were asthenosphere-derived komatiites with approximately 20-25\% $\mathrm{MgO}$ that had assimilated the quartzitic floor rocks.

The bulk of the previously analyzed B1 suite has a more enriched composition than the NG2 chills, with higher $\mathrm{SiO}_{2}$ and incompatible trace elements, and lower $\mathrm{MgO}, \mathrm{Cr}$, and $\mathrm{Ni}$. These magmas are also interpreted to be derived from asthenospheric komatiite, but prior to final emplacement in the Bushveld Complex they underwent additional contamination with upper crust in a staging chamber below the Transvaal Supergroup. The NG2 chilled magmas have largely escaped this contamination. A further contamination event is indicated by the strong and relatively homogenous $\delta^{18} \mathrm{O}$ values of the entire Bushveld cumulate succession (Harris et al. 2005). As this is absent in the Uitkomst Complex, stratigraphically located several km below the Bushveld Complex, the $\mathrm{O}$ contamination likely occurred in situ, possibly by flux of $\mathrm{CO}_{2}$ from devolatising floor dolomite.

The high PGE contents of the B1 suite cannot be explained by partial melting of normal asthenosphere nor fractionation nor contamination with most known crustal reservoirs. Instead, the B1 liquids could have been generated during melting of unusually PGE-rich convecting mantle containing incompletely mixed-in late veneer or material from the Earth's core. Alternatively, the plumederived B1 komatiite could have assimilated PGE from the SCLM, but whether this model is thermally feasible remains uncertain.

Acknowledgments We thank Tony Oldroyd for the production of the polished thin sections, Duncan Muir for assistance with the SEM work, Iain McDonald and Chris Harris for the ICP-MS analyses, and Dany Savard for the PGE analyses. Lew Ashwal contributed with fruitful discussions during core inspection. Two anonymous reviewers provided constructive reviews.

Open Access This article is distributed under the terms of the Creative Commons Attribution 4.0 International License (http://creativecommons.org/licenses/by/4.0/), which permits unrestricted use, distribution, and reproduction in any medium, provided you give appropriate credit to the original author(s) and the source, provide a link to the Creative Commons license, and indicate if changes were made.

\section{References}

Alard O, Griffin WL, Lorand JP, Jackson SE, O'Reilly SY (2000) Non-chondritic distribution of the highly siderophile elements in mantle sulfides. Nature 407:891-894

Anhaeusser CR, Maske S (1986) Mineral deposits of Southern Africa, vol. I and II. Geol Soc S Afr, 2335 pp
Arndt NT (2013) The lithospheric mantle plays no active role in the formation of orthomagmatic ore deposits. Econ Geol 108:1953-1970

Balaram V, Mathur R, Banakar VK, Hein JR, Rao CRM, Rao TG, Dasaram B (2006) Determination of the platinum-group elements (PGE) and gold in manganese nodule reference samples by nickel sulphide fire-assay and Te coprecipitation with ICPMS. Ind J Mar Sci 35:7-16

Barnes SJ (1989) Are Bushveld U-type parent magmas boninites or contaminated komatiites? Contrib Min Petrol 101:447-457

Barnes S-J, Maier WD (1999) The fractionation of $\mathrm{Ni}, \mathrm{Cu}$ and the noble metals in silicate and sulfide melts. In: Keays RR, Lesher CM, Lightfoot PC, Farrow CEG (eds) Dynamic processes in magmatic ore deposits and their application in mineral exploration. Geological Association of Canada, St. John's, p 13

Barnes S-J, Savard D, Bédard LP, Maier WD (2009) Selenium and sulfur concentrations in the Bushveld Complex of South Africa and implications for formation of the platinum-group element deposits. Miner Deposita 44:647-663

Barnes S-J, Maier WD, Curl E (2010) Composition of the marginal rocks and sills of the Rustenburg Layered Suite, Bushveld Complex, South Africa: implications for the formation of the PGE deposits. Econ Geol 105:1491-1511

Barnes SJ, Mungall JE, Maier WD (2015) Platinum group elements in mantle melts and mantle samples. Lithos 232:395-417

Barth MG, McDonough WF, Rudnick RL (2000) Tracking the budget of $\mathrm{Nb}$ and $\mathrm{Ta}$ in the continental crust. Chem Geol 165:197-213

Becker M, Le Roex AP (2006) Geochemistry of South African onand off-craton, Group I and Group II kimberlites: petrogenesis and source region evolution. J Petrol 47:673-703

Boudreau AE (1999) PELE-a version of the MELTS software programme for the PC platform. Comput Geosci 25:201-203

Brandon AD, Walker RJ, Morgan JW, Norman MD, Prichard HM (1998) Coupled 1860s and 187Os evidence for Core-Mantle Interaction. Science 280:1570-1573

Cawthorn RG, Davies G, Clubley-Armstrong A, McCarthy TS (1981) Sills associated with the Bushveld Complex, South Africa. Lithos 14:1-15

Curl EA (2001) Parental magmas of the Bushveld Complex, South Africa. PhD Thesis (unpubl) Monash University Australia: pp 140

Dale CW, Macpherson CG, Pearson DG, Hammond SJ, Arculus RJ (2012) Inter-element fractionation of highly siderophile elements in the Tonga Arc due to flux melting of a depleted source. Geochim Cosmochim Acta 89:202-225

Davies G, Tredoux M (1985) The platinum-group element and gold contents of the marginal rocks and sills of the Bushveld Complex. Econ Geol 80:838-848

Davies G, Cawthorn RG, Barton JM, Morton M (1980) Parental magma to the Bushveld Complex. Nature 287:33-35

Davies RD, Allsopp HL, Erlank AJ, Manton WI (1970) Sr isotopic studies on various layered mark intrusions in Southern Africa. In Visser DJL, Gruenewaldt G. von (eds.) Geol. Soc. S. Afr., Spec. Pub. No. 1, 576-93

De Waal SA, Graham IT, Armstrong RA (2006) The Lindeques Drift and Heidelberg intrusions and the Roodekraal Complex, Vredefort, South Africa: comagmatic plutonic and volcanic products of a 2055 Ma ferrobasaltic magma. S Afr J Geol 109:279-300

Donaldson CH (1982) Spinifex-textured komatiites: a review of textures, mineral compositions and layering, 211-244. In: Arndt NT (ed) komatiites. George Allen \& Unwin, London, p 526

Fiorentini ML, Barnes SJ, Maier WD, Heggie GJ (2011) Global variability in the PGE contents of komatiites. J Petrol 52:82-112

Foley SF (2008) Rejuvenation and erosion of the cratonic lithosphere. Nat Geosci 1:503-510

Gauert CDK, de Waal SA, Wallmach T (1995) Geology of the ultrabasic to basic Uitkomst Complex, estarn Transvaal, South Africa: an overview. J Afr Earth Sc 21:553-570 
Geo Labs (2001) OKUM (Ontario komatiite ultramafic) Geo Labs' inhouse reference material. Ontario Geological Survery, Sudbury, ON, Canada, p 2

Haggerty SE (1987) Metasomatic mineral titanates in upper mantle xenoliths, 671-690. In: Nixon PH (ed) Mantle Xenoliths. Wiley, Chichester, p 844

Hamilton JO (1977) Sr isotope and trace element studies of the Great Dyke and Bushveld Mafic Phase and their relation to early proterozoic magma genesis in southern Africa. J Petrol 18:24-52

Harmer RE, Sharpe MR (1985) Field relation and strontium isotope systematics of the marginal rocks of the eastern Bushveld Complex. Econ Geol 80:813-837

Harris C, Pronost JJM, Ashwal LD, Cawthorn RG (2005) Oxygen and hydrogen isotope stratigraphy of the Rustenburg layered suite, Bushveld Complex: constraints on crustal contamination. J Petrol 46:579-601

Hart RJ, McDonald I, Tredoux M, de Wit MJ, Carlson RW, Andreoli M, Moser DE, Ashwal LD (2003) New PGE and Re/Os-isotope data from lower crustal sections of the Vredefort Dome and a reinterpretation of its "crust on edge" profile. S Afr J Geol 107:173-184

Hu Z, Gao S (2008) Upper crustal abundances of trace elements: A revision and update. Chem Geol 253:205-221

Hughes HSR, McDonald I, Goodenough KM, Ciborowski TJR, Kerr AC, Davies JHFL, Selbyd D (2014) Enriched lithospheric mantle keel below the Scottish margin of the North Atlantic Craton: evidence from the Palaeoproterozoic Scourie Dyke Swarm and mantle xenoliths. Precambr Res 250(2014):97-126

Hulbert LJ, von Gruenewaldt G (1982) Nickel, copper, and platinum mineralization in the Lower Zone of the Bushveld Complex, south of Potgietersrus. Econ Geol 77:1296-1306

Humayun M (2011) A model for osmium isotopic evolution of metallic solids at the core-mantle boundary. Geochem Geophys Geosyst. doi:10.1029/2010GC003281

Jowitt SM, Keays RR (2012) Shale-hosted Ni-(Cu-PGE) mineralisation: a global overview. Trans Inst Min Metall B (Appl Earth Sci) 120:187-197. doi:10.1179/1743275812Y.0000000010

Li C, Ripley EM, Maier WD, Gomwe TES (2002) Olivine and sulfur isotopic compositions of the Uitkomst $\mathrm{Ni}-\mathrm{Cu}$ sulfide ore-bearing complex, South Africa: evidence for sulfur contamination and multiple magma emplacements. Chem Geol 188:149-159

Liebenberg L (1970) The sulfides in the layered sequence of the Bushveld igneous Complex. Geol Soc S Afr Spec Pub 1:108-208

Maier WD, Barnes S-J (2004) Pt/Pd and Pd/Ir ratios in mantle-derived magmas: a possible role for mantle metasomatism. S Afr J Geol 107:333-340

Maier WD, O'Brien H, Barnes S-J (2016) Platinum-group element contents of some Karelian and Kaapvaal kimberlites: implications for the PGE budget of the sub-continental lithospheric mantle. Abstract, IGC, Cape Town

Maier WD, Arndt NT, Curl EA (2000) Progressive crustal contamination of the Bushveld Complex: evidence from Nd isotopic analyses of the cumulate rocks. Contrib Miner Petrol 140:316-327

Maier WD, Peltonen P, Juvonen R, Pienaar C (2005) Platinum-group elements in peridotite xenoliths and kimberlite from the Premier kimberlite pipe, South Africa. S Afr J Geol 108:413-428

Maier WD, de Klerk L, Blaine J, Manyeruke T, Barnes S-J, Stevens MVA, Mavrogenes JA (2008) Petrogenesis of contact-style PGE mineralization in the northern lobe of the Bushveld Complex: comparison of data from the farms Rooipoort, Townlands, Drenthe and Nonnenwerth. Miner Deposita 43:255-280

Maier WD, Barnes SJ, Campbell IH, Fiorentini ML, Peltonen P, Barnes S-J, Smithies RH (2009) Mantle magmas reveal progressive mixing of meteoritic veneer into the early Earth's deep mantle. Nature 460:620-623

Maier WD, Peltonen P, McDonald I, Barnes SJ, Barnes S-J, Hatton C, Viljoen F (2012) The platinum-group element budget of the Kaapvaal and Karelian sub-continental lithospheric mantle: implications for mantle evolution. Chem Geol 302-303:119-135

Maier WD, Barnes S-J, Groves DI (2013) The Bushveld Complex, South Africa: formation of platinum-palladium, chrome and vanadium- rich layers via hydrodynamic sorting of a mobilized cumulate slurry in a large, relatively slowly cooling, subsiding magma chamber. Miner Deposita 48:1-56

Maier WD, Rasmussen B, Fletcher I, Godel B, Barnes SJ, Fisher L, Yang S, Huhma H, Lahaye Y (2015) Petrogenesis of the 2.77 Ga Monts de Cristal Complex, Gabon: evidence for direct precipitation of Pt- arsenides from basaltic magma. J Petrol 56:1285-1308

McDonald I, Holwell DA (2011) Geology of the northern Bushveld Complex and the setting and genesis of the Platreef $\mathrm{Ni}-\mathrm{Cu}-\mathrm{PGE}$ deposit. In: Li C, Ripley EM (eds) Magmatic Ni-Cu and PGE deposits: geology, geochemistry, and genesis. Reviews in Economic Geology, vol 17. Society of Economic Geologists, Littleton, USA, pp 297-327

McDonald I, Viljoen KS (2006) Platinum-group element geochemistry of mantle eclogites: a reconnaissance study of xenoliths from the Orapa kimberlite. Botswana Trans Inst Min Metall 115:81-93

McDonough WF, Sun S-S (1995) The composition of the Earth. Chemical Geology 120:223-253

Molnár F, Mänttäri I, O’Brien H, Lahaye Y, Pakkanen L, Johanson B, Käpyaho A, Sorjonen-Ward P, Whitehouse M, Sakellaris G (2016) Boron, sulphur and copper isotope systematics in the orogenic gold deposits of the Archaean Hattu schist belt, eastern Finland. Ore Geol Rev 77:133-162

Mungall JE, Brenan JM (2014) Partitioning of platinum-group elements and $\mathrm{Au}$ between sulfide liquid and basalt and the origins of mantle-crust fractionation of the chalcophile elements. Geochim Cosmochim Acta 125:265-289

Naldrett AJ, Singh J, Krstic S, Li C (2000) The mineralogy of the Voisey's Bay $\mathrm{Ni}-\mathrm{Cu}-\mathrm{Cu}$ deposit, northern Labrador, Canada: influence of oxidation state on textures and mineral compositions

Peregoedova A, Barnes S-J, Baker DR (2006) An experimental study of mass transfer of platinum-group elements, gold, nickel and copper in sulfur-dominated vapor at magmatic temperatures. Chem Geol 235:59-75

Rajesh HM, Chisonga BC, Shindo K, Beukes NJ, Armstrong RA (2013) Petrographic, geochemical and SHRIMP U-Pb titanite age characterization of the Thabazimbi mafic sills: extended time frame and a unifying petrogenetic model for the Bushveld Large Igneous Province. Precambr Res 230(2013):79-102

Reichhardt FJ (1994) The Molopo Farms Complex, Botswana: history, stratigraphy, petrography, petrochemistry and $\mathrm{Ni}-\mathrm{Cu}-\mathrm{PGE}$ mineralisation. Explor Min Geol 3:263-284

Reischmann T (1995) Precise U/Pb age determination with baddeleyite $(\mathrm{ZrO} 2)$, a case study from the Phalaborwa igneous complex, South Africa. S Afr J Geol 98:1-4

Richardson SH, Shirey SB (2008) Continental mantle signature of Bushveld magmas and coeval diamonds. Nature 453:910-913

Rudnick RL, Fountain DM (1995) Nature and composition of the continental crust: a lower crustal perspective. Rev Geophys 33:267-309

Rudnick RL, Gao S (2003) Composition of the Continental Crust. In: Holland HD, Turekian KK (eds) Treatise on Geochemistry, vol 3. Elsevier, Oxford, pp 1-64

Savard D, Barnes S, Meisel T (2010) Comparison between nickelsulfur fire assay Te Co-precipitation and isotope dilution with high-pressure asher acid digestion for the determination of platinum-group elements, rhenium and gold. Geostand Geoanal Res 34:281-291

Schmidt G, Palme H, Kratz K-L (1997) Fractionation of highly siderophile elements in the Earth's upper continental crust, Yearbook Inst. Nucl Chem, p 15, Mainz, Germany 
Schönberg R, Kruger FJ, Nagler TF, Meisel T, Kramers JD (1999) PGE enrichment in chromitite layers and the Merensky Reef of the western Bushveld Complex; a Re-Os and $\mathrm{Rb}-\mathrm{Sr}$ isotope study. Earth Planet Sci Lett 172:49-64

Sharpe MR (1981) The chronology of magma influxes to the eastern compartment of the Bushveld Complex, as exemplified by its marginal border group. J Geol Soc Lond 138:307-326

Simonson BM, Glass BP (2004) Spherule layers-records of ancient impacts. Annu Rev Earth Planet Sci 32:329-361

Sun S-S, McDonough WF (1989) Chemical and isotopic systematics of oceanic basalts: implications for mantle composition and processes. In: Saunders AD, Norry MJ (eds),Magmatismin theOcean Basins:Geol Soc, Special Publication 42, pp. 313-345

Teigler B (1990) Mineralogy, petrology and geochemistry of the lower and lower Critical Zones, northwestern Bushveld Complex. Ph.D. thesis, Rhodes University, Grahamstown, South Africa

Teigler B, Eales HV (1996) The lower and critical zones of the western limb of the Bushveld Complex, as indicated by the Nooitgedacht boreholes. Geol Surv S Afr Bull 111, $126 \mathrm{pp}$

Twist D, French BM (1983) Voluminous acid volcanism in the Bushveld Complex: a review of the Rooiberg Felsite. Bull Volc 46:225-242

Von Gruenewaldt G, Behr SH, Wilhelm HJ (1989) Some preliminary petrological investigations of the Molopo Farms Complex, Botswana, and its $\mathrm{Ni}-\mathrm{Cu}$ sulphide mineralization. Magmatic sulfides - the Zimbabwe volume. The Institution of Mining and Metallurgy, London, 95-105
Walraven F, Hattingh E (1993) Geochronology of the Nebo granite, Bushveld Complex. S Afr J Geol 96:31-41

Wenzel T, Baumgartner LP, Bruegmann GE, Konnikov EG, Kislov EV (2002) Partial melting and assimilation of dolomitic xenoliths by mafic magma: the Ioko Dovyren intrusion, North Baikal Region, Russia. J Petrol 43:2049-2074

Wille M, Kramers JD, Nägler TF, Beukes NJ, Schröder S, Meisel T, Lacassie JP, Voegelin AR (2007) Evidence for a gradual rise of oxygen between 2.6 and $2.5 \mathrm{Ga}$ from Mo isotopes and Re-PGE signatures in shales. Geochim Cosmochim Acta 71:2417-2435

Wilson AH (2012) A chill sequence to the Bushveld Complex: insight into the first stage of emplacement and implications for the parental magmas. J Petrol 53:1123-1168

Wilson MGC, Anhaeusser CR (1998) The mineral resources of South Africa, Council for Geoscience, Handbook 16, $740 \mathrm{pp}$

Workman RK, Hart SR (2005) Major and trace element composition of the depleted MORB mantle (DMM). Earth Planet Sci Lett 231:53-72

Yang S, Maier WD, Lahaye Y, O’Brien H (2013) Strontium isotope disequilibrium of plagioclase in the Upper Critical Zone of the Bushveld Complex: evidence for mixing of crystal slurries. Contrib Miner Petrol. doi:10.1007/s00410-013-0903-4

Yudovskaya MA, Kinnaird JA, Sobolev AV, Kuzmin DV, McDonald I, Wilson AH (2013) Petrogenesis of the lower zone olivinerich cumulates beneath the Platreef and their correlation with recognized occurrences in the Bushveld Complex. Econ Geol 108:1923-1952 